\title{
Development of Hot Pressing as a Low Cost Processing Technique for Fuel Cell Fabrication
}

\author{
Final Annual Technical Progress Report
}

January 06, 2003

Research sponsored by the U.S. Department of Energy,

Office of Fossil Energy

Advanced Research and Technology Development Materials Program

Report Prepared by

Vinod Sarin, Uday Pal, and Srikanth Gopalan

Department of Manufacturing Engineering,

Boston University

15 St. Mary's Street,

Boston, MA-02215

for

OAKRIDGE NATIONAL LABORATORY

Oak Ridge, Tennessee 37831

Managed by

LOCKHEED MARTIN ENERGY RESEARCH CORPORATION

For the

U.S. DEPARTMENT OF ENERGY

under Contract No. DE-AC05-96OR2264 


\section{TABLE OF CONTENTS}

List of Tables $\quad$ iv

List of Figures $\quad$ v

1. INTRODUCTION 1

1.1. Obstacles to Commercialization 2

1.2. Hot Pressing 4

1.2.1. Novel SOFC Processing Technique 4

2. EXPERIMENTAL DETAILS 8

2.1. Typical Hot Pressing Cycle 8

2.2. Hot Pressing Experiments: Reducing Environment 8

2.3. Hot Pressing Experiments: Oxidizing Environment 10

3. RESULTS AND DISCUSSION

3.1. Experimental Regime 12

3.1.1. Equipment Limits 13

3.1.2. Chemical Interactions 14

3.1.3. Established Sintering Cycles $\quad 15$

3.1.4. Particle Size Considerations 16

3.2. Experimental Approach Summary 19

3.3. Electrolyte Development 19

3.4. Cathode Development 22

3.5. Anode Development 23

3.5.1. Elimination of Ni Reaction Layer 26 
$\begin{array}{ll}\text { 3.5.2. Oxidizing Environment } & 28\end{array}$

3.6. Anode 2: Mo and YSZ 29

3.7. Anode 3: $\mathrm{Mo} / 3 \% \mathrm{Ni}$ and YSZ 31

3.8. Single Cell 33

3.9. Electrochemical Characterization 33

4. CONCLUSIONS

7. Appendix A 36

8. Appendix B 39

9. Bibliography 41 


\section{LIST OF TABLES}

Table $\quad 3.5 \quad$ Percentage of Driving Force Due to Applied Pressure 18

Table $\quad 3.7$ Relative Density Estimations as a Function of Hot Pressing 20 Temperatures for Hot Pressed YSZ Powder 


\section{LIST OF FIGURES}

Figure $\quad 1.1$ Cost Comparison of Selected Power Generating Systems 3

Figure $\quad 1.2$ Schematic Representation of SOFC Hot Pressing Technique 4

Figure $\quad 1.3$ Schematic Representation of Novel Hot Pressing Technique 5

$\begin{array}{llll}\text { Figure } & 1.4 & \text { Evolution of Hot Press Technique into High Yield } & 7\end{array}$

$\begin{array}{llll}\text { Figure } & 2.1 & \text { Typical Hot Pressing Cycle } & 9\end{array}$

Figure 3.1 Experimental Approach to Hot Pressing a Single Cell 12

$\begin{array}{lll}\text { Figure } & 3.2 & \text { Experimental Operating Regime }\end{array}$

Figure $\quad 3.3$ Practical SOFC Hot Pressing Experimental Regime 14

Figure $\quad 3.4$ Practical SOFC Hot Pressing Experimental Regime 16

$\begin{array}{lll}\text { Figure } & 3.6 & \text { Summary of Experiments }\end{array}$

Figure $\quad 3.8$ Optical Microscopy of Electrolyte Cross Section of Hot Pressed 21

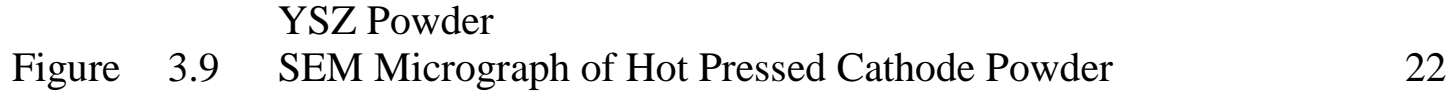

Figure 3.10 Equilibrium Oxygen Partial Pressure of Ni and NiO as a 26

Figure 3.11 Various Hot Pressed Anode Powders 27

Figure $\quad 3.12 \mathrm{NiO}$ Powder Hot Pressed in an Oxidizing Environment 29

Figure $\quad 3.13$ Hot Pressed Mo/ YSZ Anode Powder and YSZ Electrolyte 30

Figure 3.14 Mo - Ni Binary Phase Diagram 32

Figure $\quad 3.15$ Mo-Based Anode and Electrolyte Half Cells 32

Figure 3.16 Mo-Based Anode, Single Cell, in a Reducing Environment 34 


\section{Chapter 1}

\section{INTRODUCTION}

Dependable, plentiful, and economical energy has been the driving force for financial, industrial, and political growth in the United States since the mid $19^{\text {th }}$ century. For a country whose progress is so deeply rooted in abundant energy and whose current political agenda involves stabilizing world fossil fuel prices, the development of a reliable, efficient and environmentally friendly power generating source seems compulsory. The maturing of high technology fuel cells may be the panacea the country will find indispensable to free itself from foreign dependence. Fuel cells offer an efficient, combustion-less, virtually pollution-free power source, capable of being sited in downtown urban areas or in remote regions. Fuel cells have few moving parts and run almost silently.

Fuel cells are electrochemical devices that convert the chemical energy of a fuel directly to electrical energy. Unlike batteries, which store a finite amount of energy, fuel cells will generate electricity continuously, as long as fuel and oxidant are available to the electrodes. Additionally, fuel cells offer clean, efficient, and reliable power and they can be operated using a variety of fuels. Hence, the fuel cell is an extremely promising technology. 


\section{Obstacles to Commercialization}

The capital cost associated with SOFCs is still prohibitively high. Fig. 1.1 offers a comparison of the capital costs of several power generating systems. The most widely marketed fuel cell, an AFC, by International Fuel Cell, is only used where money is not an issue, i.e., for continuous power demands and in space applications, it is not a price level where in can reach the mass market.

There are two major obstacles for commercializing the Solid Oxide Fuel Cell technology: reducing processing cost and increasing operating lifetime. Cost problems arise from expensive and time intensive batch processing, while operating lifetime issues result from material incompatibilities (thermal expansion mismatch) causing thermal cycling problems such as delamination, thermal shock, and distortion or cracking.

The cost reduction necessary for commercialization of SOFC technology will not be met by optimization alone. Mass production techniques must be developed for SOFCs to be competitive with current power generating devices. There is a limit to the premium that customers will be willing to pay for environmentally friendly power or even higher

efficiencies. The current cost goal of $\$ 400$ per kilowatt can only be met by improved processing techniques. 


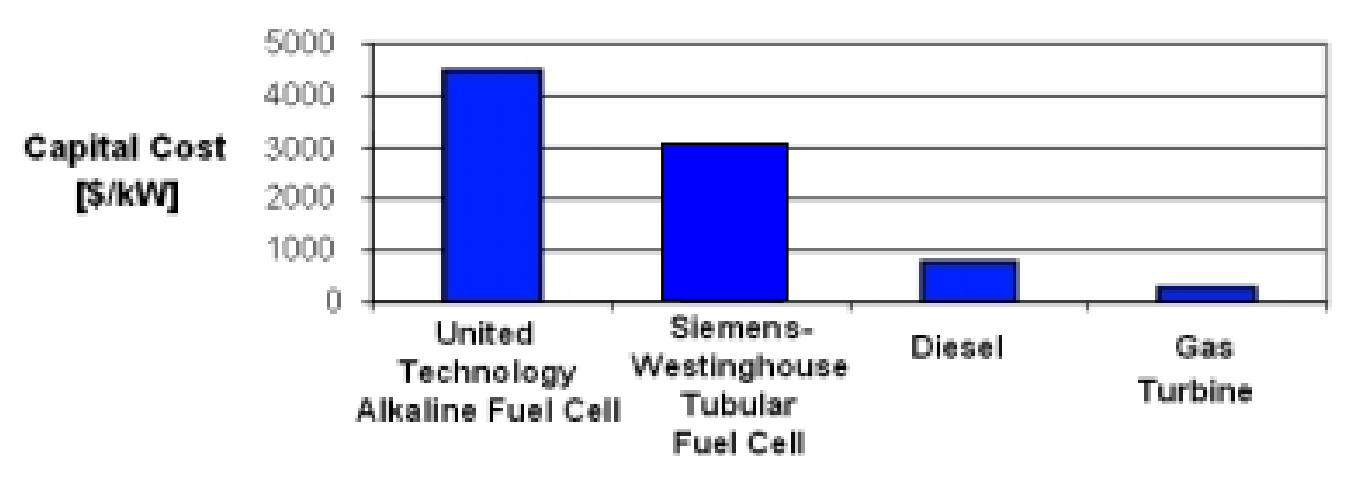

Power Generating Systems

Figure 1.1: Cost Comparison of Selected Power Generating Systems [13].

Some of the most energy intensive and expensive fabrication processes, for any SOFC stack design, are the high temperature sintering steps. Batch processes, in the tubular and planar designs, use repeated thermal cycling steps to sinter successive layers upon previous ones. The monolithic design improves upon this approach by co-firing all layers in a cell in one step, thereby eliminating the batch processing. However, the monolithic design incorporates extensive post process non-destructive testing and evaluation due to the complex geometries and multiple shrinkage rates encountered during processing. This extraneous post testing substantially increases the overall fabrication cost.

Therefore an improved fabrication process is desired, which would reduce or remove the number of separate batch processes required to produce a SOFC without adding extreme post process testing.

This is the approach currently being undertaken at Boston University (BU). Researchers at $\mathrm{BU}$ have shown preliminary results using an alternative ceramic 
processing technique to eliminate batch, without the added geometrical complexity of the monolithic design.

\section{Hot Pressing}

Hot pressing is the simultaneous application of elevated temperature and compressive stress to consolidate fine green pressed powders into partially or fully sintered components. The technique, shown in Fig. 1.2, was developed for the powder metallurgy industry and has been successfully applied to ceramic components over the last several decades $[14,15]$. Pressure increases the driving force for densification, in effect, reducing the processing temperature required for a sintering process. Also, hot pressing results in smaller overall grain size, more precise control over the microstructure and the flexibility of functionally grading the ceramic layers.

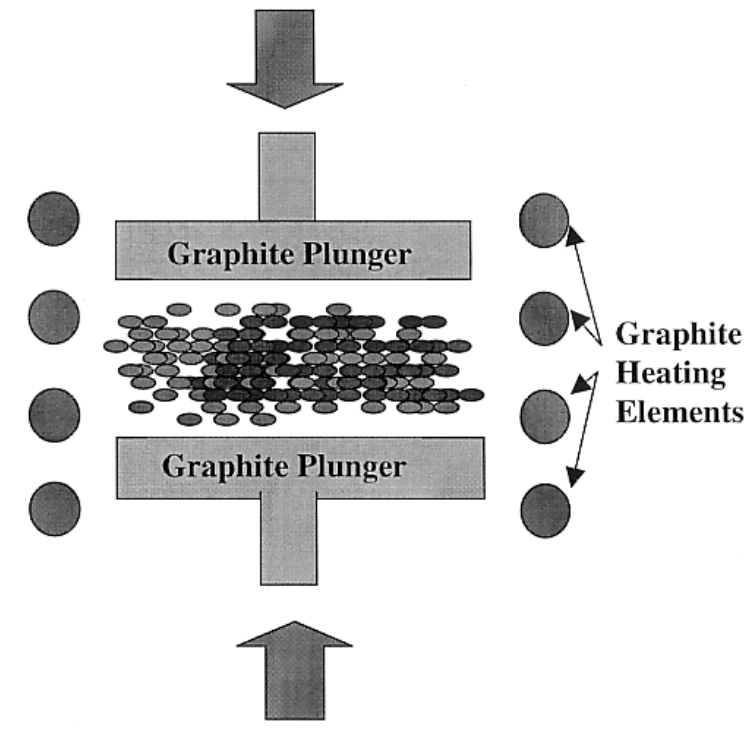

Figure 1.2: Schematic Representation of SOFC Hot Pressing Technique. 
Novel SOFC Processing Technique

Hot pressing as was investigated at Boston University a novel processing technique to fabricate the planar SOFC in a single step. The densification parameters of each individual component were individually determined. Then, by optimizing the densification parameters for the different layers, the entire fuel cell was hot pressed in a single step. By removing multiple batch processing steps and simplifying the manufacturing process, considerable cost reduction can be achieved over current manufacturing processes. Additionally, the flexibility of hot pressing can improve interfacial contact and allows for functional grading of interfaces to reduce polarization losses. Finally, by optimizing the process, the processing time and cost can be greatly reduced. Hot pressing has never before been applied to the fabrication of SOFCs. A schematic representation of how a single cell can be processed is shown in Fig. 1.3.

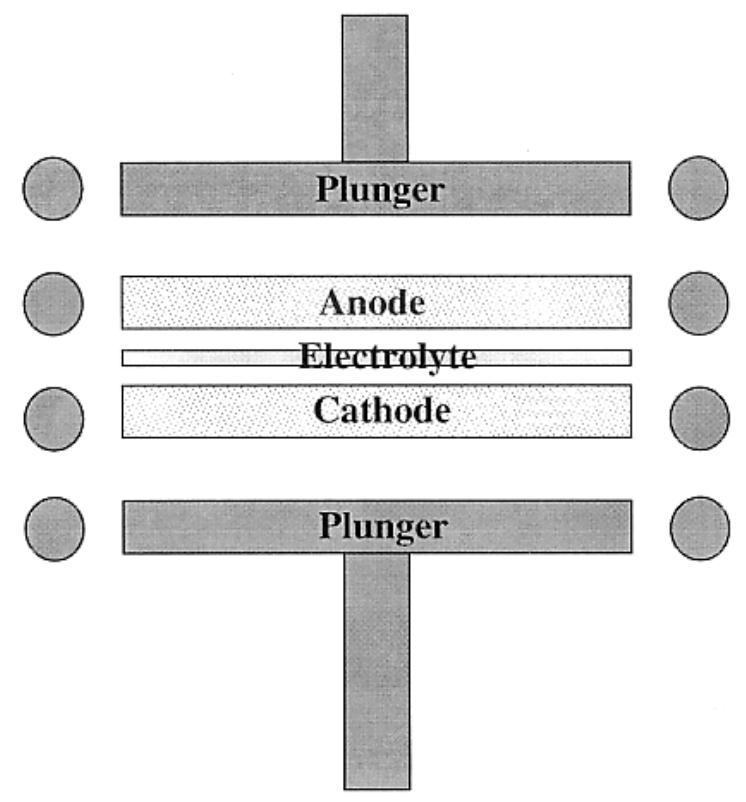

Figure 1.3: Schematic Representation of Novel SOFC Hot Pressing Technique 
Although reducing the processing to one step, a commercial hot press is a very capital intensive investment. Hot pressing also requires long heat-up times $\left( \pm 5^{\circ} \mathrm{C} / \mathrm{min}\right)$ leading to a relatively slow cycle time. To overcome these limitations it is proposed to fabricate many cells at once, this is shown schematically in Fig. 1.4. In this schematic many single cells, consisting of anode, cathode, and electrolyte, will be pressed between inert spacers. Since each cell can be individually tested, one bad cell will not ruin an entire stack, as in the monolithic design allowing for a reduction in scrap rate.

With a typical commercially available hot press, one can easily press a single cell area of $25 \mathrm{~cm} \times 25 \mathrm{~cm}\left(625 \mathrm{~cm}^{2}\right)$. Furthermore, since the thickness of each cell is not expected to exceed 4 to $5 \mathrm{~mm}$, at least 20 cells can be fabricated at one time in a single hot-pressing operation. Operated continuously one hot press one could effectively produce a total cell area of $37,500 \mathrm{~cm}^{2} /$ day. It is therefore reasonable to project that with 3 to 4 hot presses one could obtain $12-15 \mathrm{~m}^{2}$ of cell area per day. Thus hot pressing can be a high-volume one step manufacturing process that will result in lower cost, lower processing time, improved interfacial contact (lower polarization losses) and lower thermal stresses at the interfaces as a result of compositionally grading the interfaces.

The purpose of this research is to develop the fundamental knowledge related to ceramic processing, sintering, and hot pressing which must be known to successfully hot press a single operational SOFC in one step. 


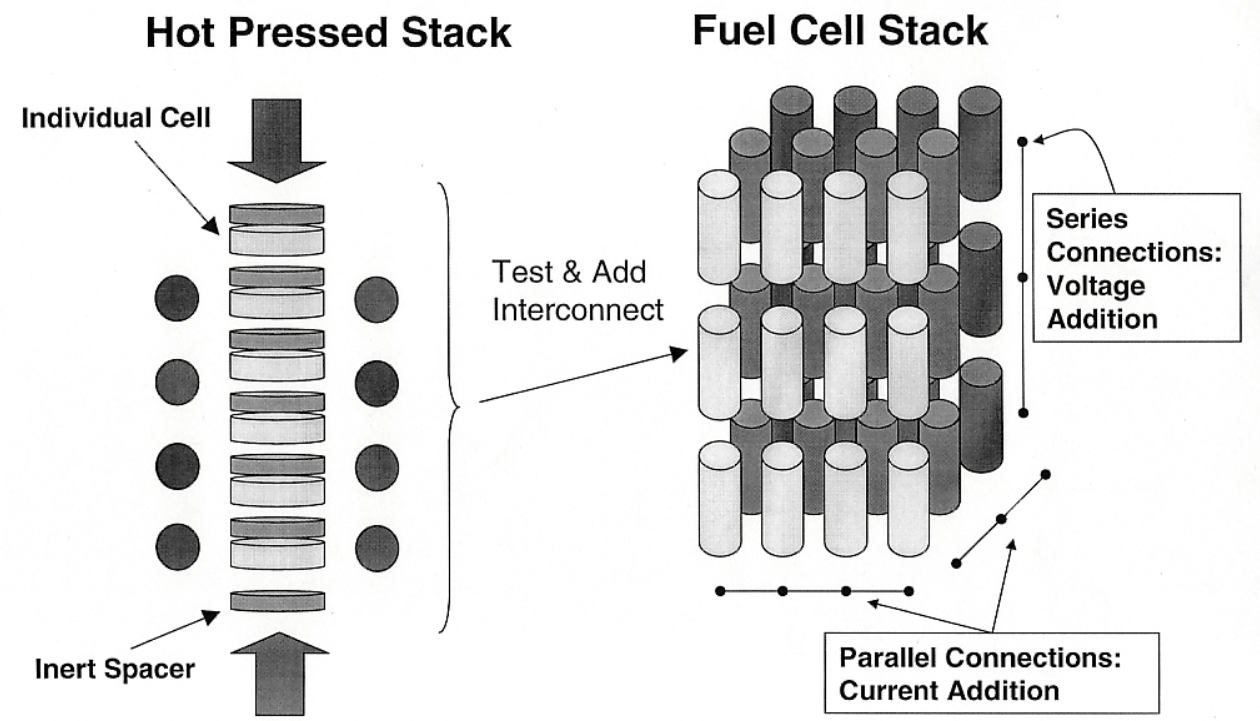

Figure 1.4: Evolution of Hot Press Technique into High Yield Manufacturing Process. 


\title{
Chapter 2
}

\section{EXPERIMENTAL DETAILS}

\author{
Typical Hot Pressing Cycle
}

The final hot pressed microstructure is controlled by three primary parameters: temperature, pressure, and time. As shown in the theoretical section, temperature, pressure, and time have decreasing amounts of effectiveness in changing the initial microstructure.

An example of a pressured assisted sintering cycle for pore closure in cemented carbide ceramics is plotted in Fig. 2.1. A key attribute is the simultaneous application of maximum temperature and pressure. This cycle has been shown to give the smallest open porosity [27]. This approach has been taken in this research to ensure a fully dense electrolyte at the lowest temperature possible. Secondary parameters such as particle size distribution, green density and added binders are ignored in this representation.

Hot Pressing Experiments: Reducing Environment

The experiments were conducted in a Centorr hot-press with graphite heating elements resulting in a reducing environment. The chamber temperature was measured 
with a ' $\mathrm{W}$ ' type thermocouple and was also cross-checked with an optical pyrometer. The pressure was calculated based on the applied load by the hydraulic pump on the ram and the cross-sectional area of the die. The vertical movement of the ram was monitored by a micrometer. The chamber was connected to a mechanical pump to obtain the desired chamber pressure. Argon was backfilled to create an approximately inert atmosphere in the chamber when required.

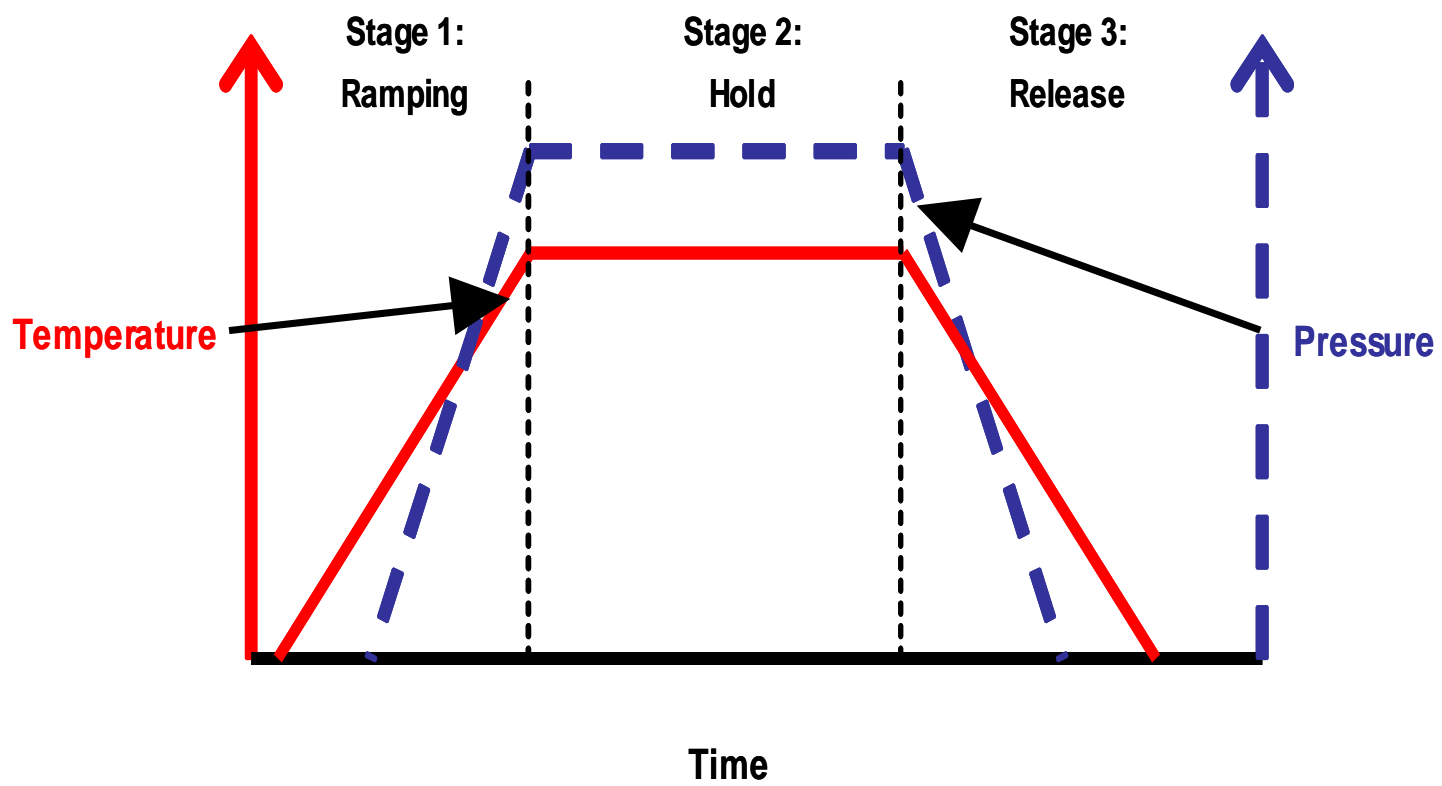

Figure 2.1: Typical Hot Pressing Cycle

The green compact, either individual or multi-component layers, were placed in the hot press and the chamber was evacuated and purged with argon to remove contaminants. The powder was then slowly heated at $3^{\circ} \mathrm{C}$ per minute, while maintaining a maximum pressure of 100 mTorr. The hot press was connected to a Honeywell digital control programmer. The desired temperature-pressure-time cycles were programmed 
into the controller which were then executed and plotted automatically. The automatic program was activated, at approximately $400{ }^{\circ} \mathrm{C}$, and allowed to bring the hot press through its heating and pressure cycles.

Hot Pressing Experiments: Oxidizing Environment

A custom resistance furnace was attached to an Instron mechanical testing machine in order to hot press samples in a high oxygen partial pressure environment. A cylindrical convection furnace was purchased from Hi-Temp Products Corp., of Danbury, Connecticut. An aluminum stand was fabricated to support this furnace on the Instron frame. 303 Stainless Steal rods with Inconel 600 tips were used as plungers. Several die materials were used including Inconel and alumina. Temperature was manually controlled by a $240 \mathrm{~V}$ variac connected to super kanthal heating element leads. Pressure was controlled by the Instron machine. The die assembly was fabricated from Alumina to ensure high temperature stability in an oxidizing environment. Machinable alumina rod, of $75 \%$ relative density and $7.5 \mathrm{~cm}$ diameter was used for the die sleeve. Fully dense $\mathrm{Al}_{2} \mathrm{O}_{3}$ rods, of $0.8 \mathrm{~cm}$ diameter, were also used for the plungers. 


\section{Chapter 3}

\section{RESULTS AND DISCUSSION}

To produce high quality reliable cells, the hot pressing SOFC fabrication process must maintain: a fully dense electrolyte, porous electrodes, adequate interfacial bonding, and minimal material interactions during fabrication. Ensuring these requirements necessitate careful and controlled examination of individual components before the components can be combined into a single cell.

In order to determine the ideal processing conditions for the different material component layers, the three components of focus in this study, anode, cathode and electrolyte, were initially studied independently. Only after establishing individual densification characteristics, were the components combined and studied in tandem.

Although further details are given below, the experimental approach is outlined presently and is summarized in Fig. 3.1. Initially a moderate pressure was selected. A moderate pressure was chosen so that in the future the pressure could be increased or decreased as needed. This pressure was used for all components to establish a baseline for comparison. Secondly, a starting temperature was chosen. After this, a hold time was verified. The initial time was considered adequate if double the time did not give any gross microstructural changes. Next a temperature range was iterated upon to establish the minimum possible process temperature. Finally, secondary parameters such as 
particle size, particle packing, particle distribution or pressure modifications were used to tailor the microstructure to the design goals.

\section{Experimental Regime}

It was important to understand the extent of the experimental regime before trials were commenced. This regime was limited by equipment, chemical interactions and previously established sintering cycles.

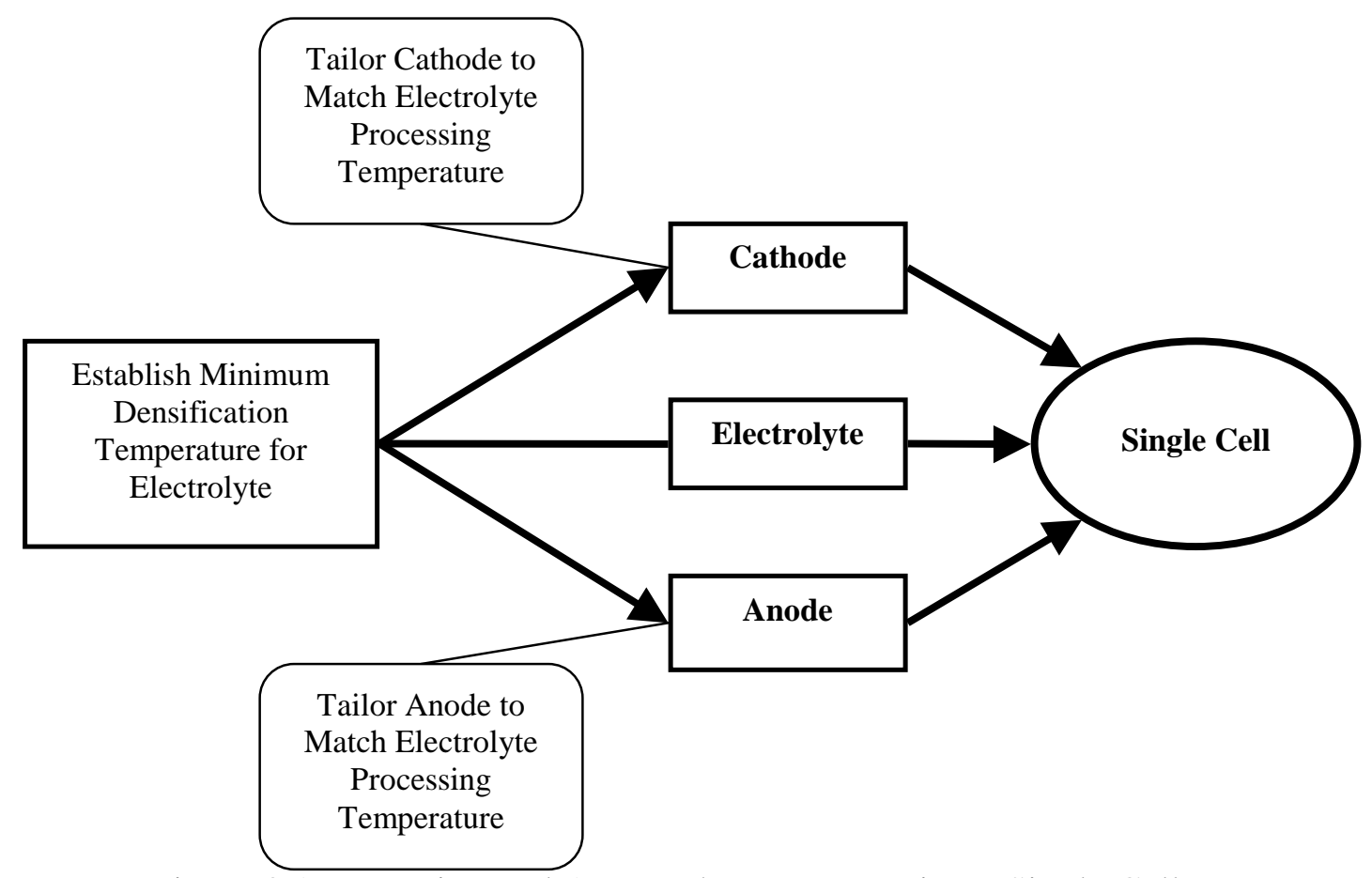

Figure 3.1: Experimental Approach to Hot Pressing a Single Cell. 


\section{Equipment Limits}

The maximum operating temperature of the graphite heating elements used in the hot press was $2500^{\circ} \mathrm{C}$. Therefore $2500^{\circ} \mathrm{C}$ was the absolute upper limit for the fabrication temperature. All hot pressing experiments were initially conducted in a graphite die and sleeve fixture. The reported maximum compressive stress of for high density, finegrained structural graphite is 15,000 to $18,000 \mathrm{psi}$, from room temperature to $2500^{\circ} \mathrm{C}$ [41]. Assuming a safety factor of $2 / 3$, a maximum pressure limit of 10,000 psi was assigned. Therefore a pressure range of 0 to 10,000 psi was used for these experiments. This region was further divided into moderate pressure, 0- $5000 \mathrm{psi}$, and high pressure 5000-10, 000 psi. This is schematically summarized in Fig. 3.2.

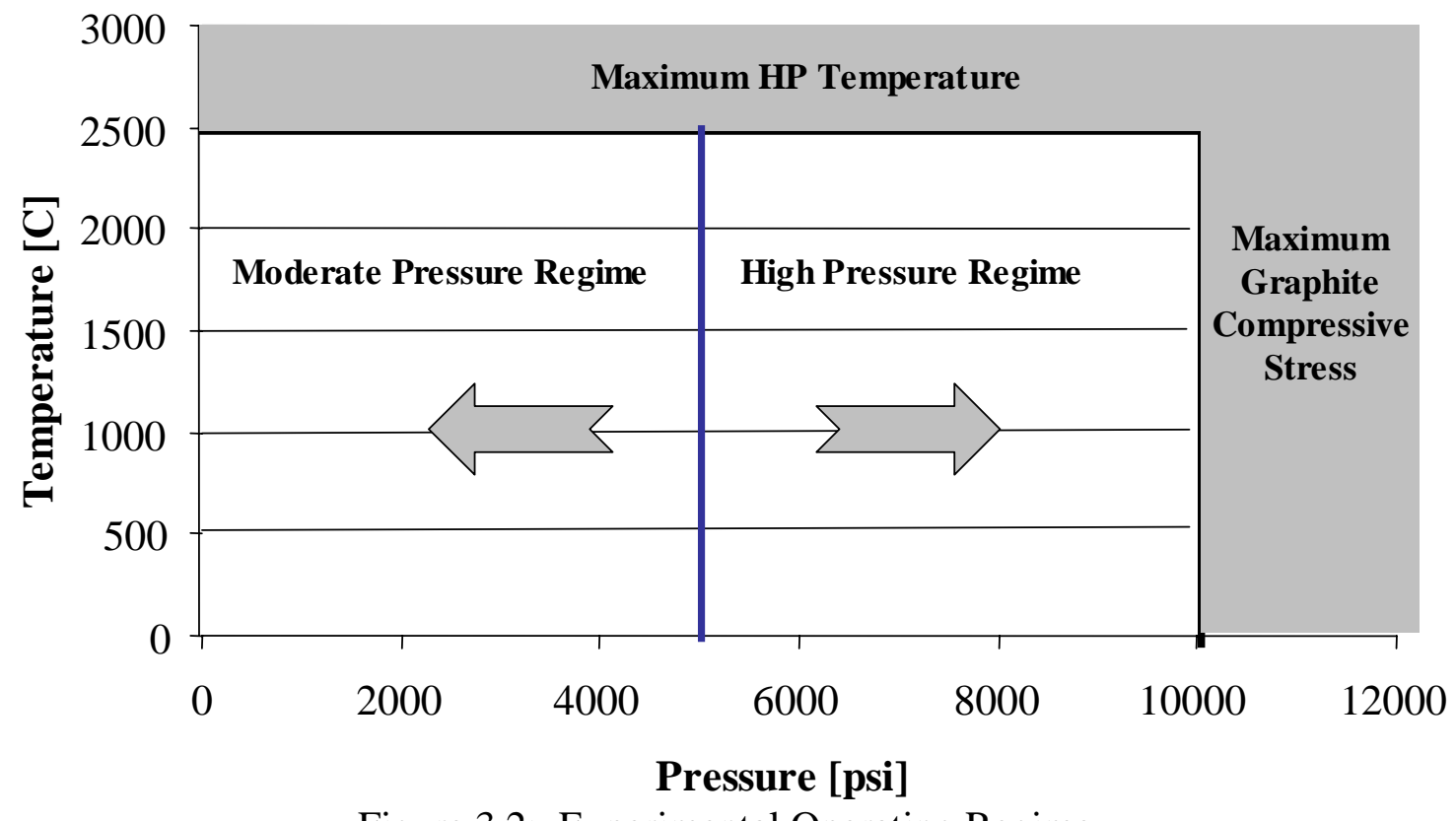

Figure 3.2: Experimental Operating Regime. 


\section{Chemical Interactions}

Chemical interactions between the components become important at higher temperature. Therefore the maximum temperature before interactions begin was established.

Thermodynamically, $\mathrm{ZrO}_{2}$ reacts with $\mathrm{LaMnO}_{3}$ to form insulating phases such as $\mathrm{La}_{2} \mathrm{Zr}_{2} \mathrm{O}_{7}$ between the cathode and electrolyte, at temperatures above $1100^{\circ} \mathrm{C}[42,43,44$, 45]. Although the reaction kinetics of this reaction are slow, these insulating phases are undesirable in SOFCs and must be minimized because they hinder electronic conduction in the cathode causing cell performance to degrade significantly.

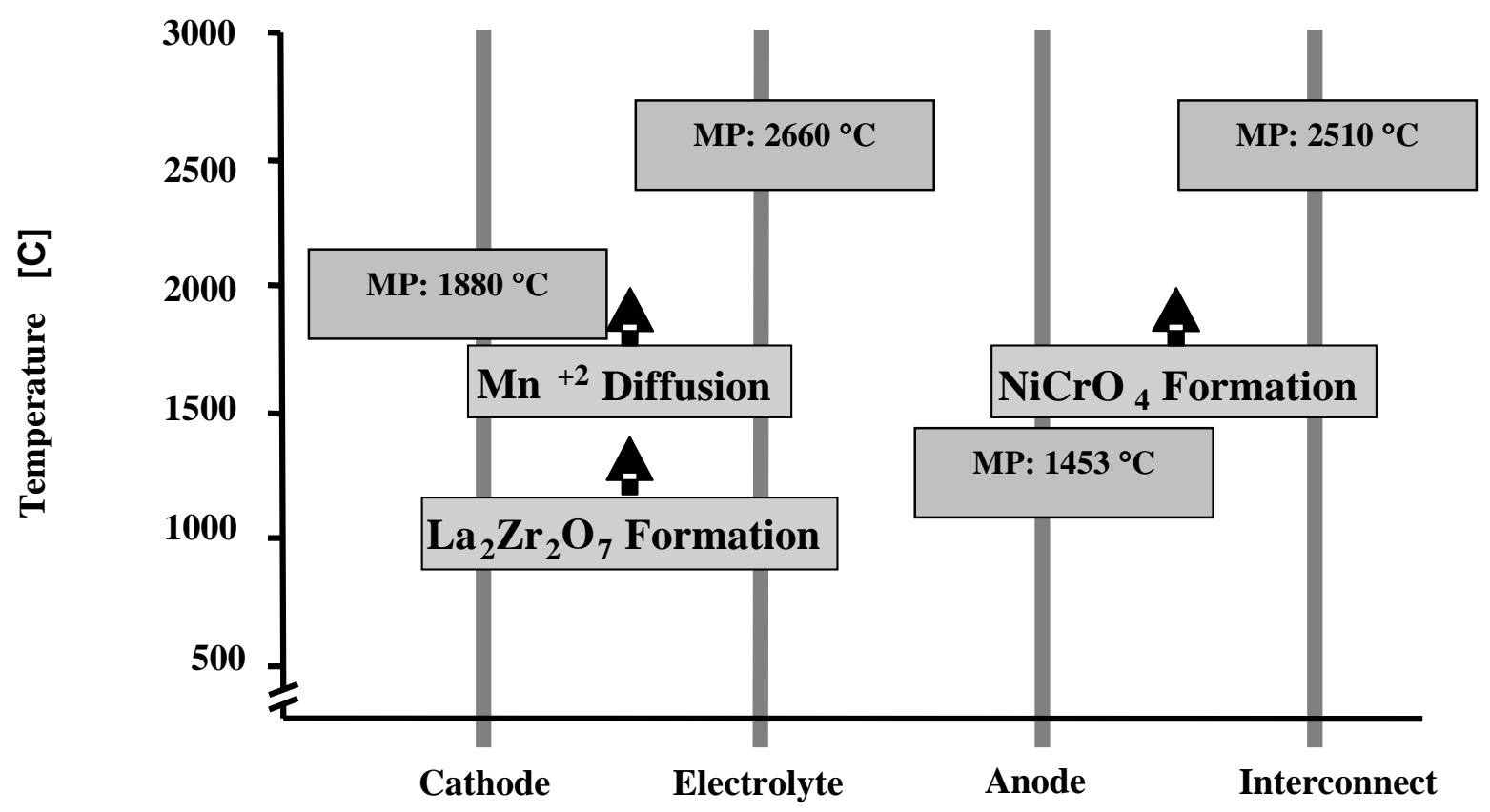

Figure 3.3: Practical SOFC Hot Pressing Experimental Regime 
Manganese is known to be a mobile species at high temperatures and can easily diffuse into the electrolyte, changing the electrical characteristics or the structure of both the cathode and the electrolyte [46]. Fabrication temperature was limited to below $1400^{\circ} \mathrm{C}$ to minimize this migration. Also, above $1400^{\circ} \mathrm{C}, \mathrm{Ni}$ or $\mathrm{NiO}$ may react with the $\mathrm{LaCrO}_{3}$ interconnect material to form poorly conducting phases such $\mathrm{NiCrO}_{4}$ [47]. Finally, elemental Nickel melts at $1453^{\circ} \mathrm{C}$. These facts suggested a maximum processing temperature of $1400^{\circ} \mathrm{C}$, lower if possible. These facts, as well as the melting points of the SOFC component materials are summarized in Fig. 3.3

\section{Established Sintering Cycles}

The monolithic fuel cell fabrication temperature using tape calendaring and pressure-less sintering was reported to lie between 1300 and $1400^{\circ} \mathrm{C}[27,48]$.

Zirconia powder, of $0.1 \mu \mathrm{m}$ mean diameter, was sintered to $98 \%$ theoretical density at $1300^{\circ} \mathrm{C}$ in air [50]. YSZ powders of sub-micrometer size were formed into a green body (about $50 \%$ green density) and fired to $95 \%$ theoretical density in air at $1125^{\circ} \mathrm{C}$ [51]. These data suggest a starting point for hot pressing zirconia to full density of $1100^{\circ} \mathrm{C}$ to $1300^{\circ} \mathrm{C}$.

Nickel powder, of $0.5 \mu \mathrm{m}$ particle size, was sintered at $800^{\circ} \mathrm{C}$ to $98 \%$ theoretical density [49]. This suggests that Ni powder will not yield the $30-40 \%$ porosity required for a $\mathrm{SOFC}$ anode. However, $\mathrm{NiO}$ powder of $0.3 \mu \mathrm{m}$ mean particle size was fired to $57 \%$ theoretical density at $900^{\circ} \mathrm{C}$ [49]. This suggests that $\mathrm{NiO}$ powder will yield the $30-40 \%$ 
porosity required for a SOFC anode. This is consistent with the established processing of the anode using $\mathrm{NiO}$ powder as described in the introductory section.

The LSM cathode was air sintered at $1250^{\circ} \mathrm{C}$, to the required porosity level [18]. Since an additional driving force for densification, arising from the applied pressure, was available in hot pressing, this ensured densification to the required porosity at or below $1250^{\circ} \mathrm{C}$.

Based on the above information, the limitation to the experimental regime imposed by previously established sintering cycles is summarized in Fig. 3.4.

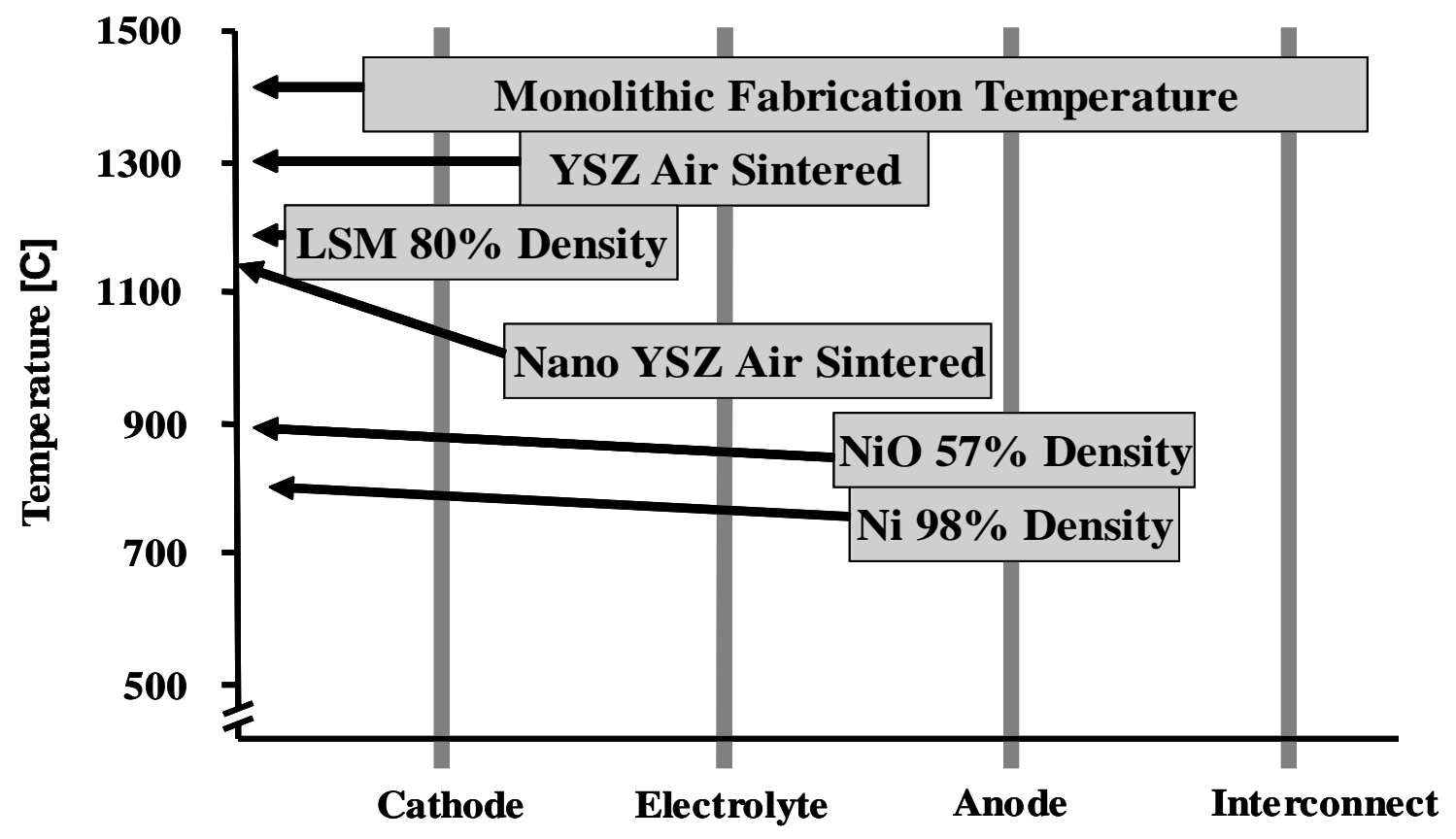

Figure 3.4: Practical SOFC Hot Pressing Experimental Regime 
Based on equipment, material interaction and established sintering cycle limitations, the overall hot pressing experimental regime was established as between 900 to $1300^{\circ} \mathrm{C}$, and less than 10,000 psi.

\section{Particle Size Considerations}

In certain particle size and pressure regimes surface energy or applied pressure can dominate the driving force for densification. Therefore, it is critical to carefully select initial powder particle sizes and starting pressures prior to beginning experimental hot pressing studies.

The relative increase in vacancy concentration arising from surface energy relative to applied pressure can be calculated using eq. 3.1. An alternative way of showing these effects is by calculating an equivalent driving force for densification including both applied pressure and surface energy vacancy concentration effects. This can be derived by solving eq. 3.1 for $\Delta \mathrm{C}$ SurfaceEnergy and adding this to the applied pressure driving force, as shown in eq. 3.1.

$$
\begin{gathered}
\frac{\Delta C_{\text {Applied Pr essure }}}{\Delta C_{\text {SurfaceEnergy }}}=\frac{P_{a} R}{\pi \gamma} \\
F_{\text {EquivalentDrivingForce }}=\Delta C_{\text {Applied Pressure }}+\Delta C_{\text {Applied Pressure }}\left(\frac{\pi \gamma}{P_{a} R}\right)
\end{gathered}
$$


Using eq. 3.1, the equivalent driving force was calculated over several particle sizes and applied pressures ranges. In Table 3.5, the percentage of this driving force due to applied pressure was calculated. The surface energy, $\gamma$, used in eq. 3.1, was approximated as $10^{3} \mathrm{ergs} / \mathrm{cm}^{2}$ or $1 \mathrm{~J} / \mathrm{m}^{2}$ as described by Coble [34]. As evident from the calculated values, the surface energy contribution to driving force is negligible $(<1 \%)$ for particle sizes $10 \mu \mathrm{m}$ and greater, with $2500 \mathrm{psi}$ or greater as the applied force.

\begin{tabular}{|c|c|c|c|c|c|c|}
\hline \multirow{2}{*}{$\begin{array}{c}\text { Applied } \\
\text { Pressure } \\
\text { [psi] }\end{array}$} & \multicolumn{6}{|c|}{ Particle Size Radius $[\mu \mathrm{m}]$} \\
\cline { 2 - 7 } & $\mathbf{0 . 0 1}$ & $\mathbf{0 . 1}$ & $\mathbf{1}$ & $\mathbf{1 0}$ & $\mathbf{1 0 0}$ & $\mathbf{1 0 0 0}$ \\
\hline $\mathbf{1 0 0 0 0}$ & $40.79 \%$ & $87.33 \%$ & $98.57 \%$ & $99.86 \%$ & $99.99 \%$ & $100.00 \%$ \\
\hline $\mathbf{5 0 0 0}$ & $25.62 \%$ & $77.50 \%$ & $97.18 \%$ & $99.71 \%$ & $99.97 \%$ & $100.00 \%$ \\
\hline $\mathbf{2 5 0 0}$ & $14.69 \%$ & $63.27 \%$ & $94.51 \%$ & $99.42 \%$ & $99.94 \%$ & $99.99 \%$ \\
\hline $\mathbf{1 0 0 0}$ & $6.45 \%$ & $40.79 \%$ & $87.33 \%$ & $98.57 \%$ & $99.86 \%$ & $99.99 \%$ \\
\hline $\mathbf{1 0 0}$ & $0.68 \%$ & $6.45 \%$ & $40.79 \%$ & $87.33 \%$ & $98.57 \%$ & $99.86 \%$ \\
\hline
\end{tabular}

Table: 3.5: Percentage of Driving Force Due to Applied Pressure.

Full density, or at a minimum, closed porosity is critical for an SOFC electrolyte. Therefore, it was desirable to hot press with a powder particle size where there was a significant contribution to driving force from both applied pressure and surface energy effects. Assuming 2500 psi applied pressure, a particle range between 0.1 and $1 \mu \mathrm{m}$ yielded approximately a 50\% contribution to driving force from both applied pressure and surface energy effects. However for the electrodes, densification was limited or hindered as much as possible since incomplete sintering or connected porosity is critical 
for gas transport. Therefore, with 2500 psi applied pressure, a particle size or $10 \mu \mathrm{m}$ or greater yielded less than $2 \%$ contribution, from surface energy, to the driving force for densification.

Experimental Approach Summary

For experimental hot pressing studies, it was necessary to select a starting pressure and temperature. In order to reduce internal stresses and maintain equipment a modest pressure of $2500 \mathrm{psi}$, the middle of the moderate pressure regime was initially selected. To ensure closed porosity in the electrolyte, the high end of the temperature range, $1300^{\circ} \mathrm{C}$, was initially selected.

A research approach involving the independent tailoring of the electrolyte, cathode and anode was followed as described above. Although the parameters for electrolyte and cathode densification were rapidly established, it became apparent that the conventional SOFC anode, Ni-YSZ, could not be hot pressed due to equipment limitations. New anode systems were then examined. A schematic summary of this development is outlined in Fig. 3.6.

\section{Electrolyte Development}

Initial experiments were conducted at 2500 psi applied pressure, with a $30 \mathrm{~min}$ hold time and temperatures of $1300,1200,1100$, and $1000{ }^{\circ} \mathrm{C}$. Relative density 
estimations, based on visual observation of apparent levels of porosity in the samples, are summarized in Table 3.7.

Based on these results, $1100^{\circ} \mathrm{C}$ was established as the lowest hot pressing temperature for the electrolyte. Electrolyte powder hot pressed at $1100^{\circ} \mathrm{C}$ resulted in greater than $90 \%$ relative density and closed porosity. This sample met the requirements of a SOFC electrolyte including providing a barrier between electrodes to prevent mixing of oxidant and fuel and provide a continuous ionic pathway. Optical micrographs of hot pressed electrolytes are shown in Fig. 3.8.

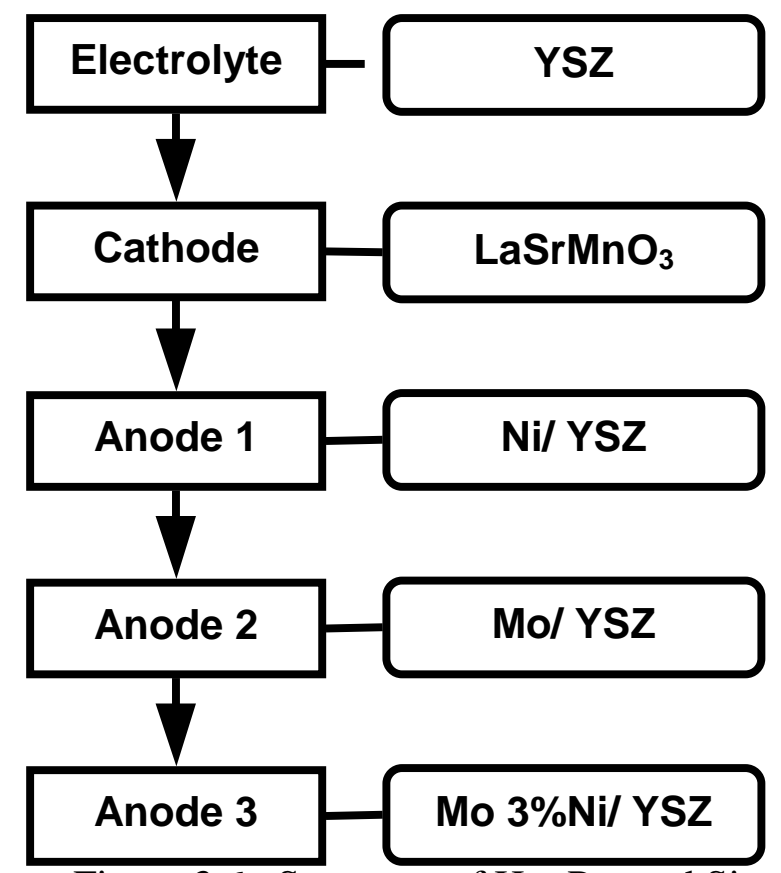

Figure 3.6: Summary of Hot Pressed Single Cell Development.

\begin{tabular}{|l|c|c|c|c|}
\hline Hot Pressing Temperature & 1300 & 1200 & 1100 & 1000 \\
\hline Relative Density & $>95 \%$ & $>95 \%$ & $>90 \%$ & $80 \%$ \\
\hline
\end{tabular}

Table 3.7: Relative Density Estimation as a Function of Hot Pressing Temperature for Hot Pressed YSZ Powder. 


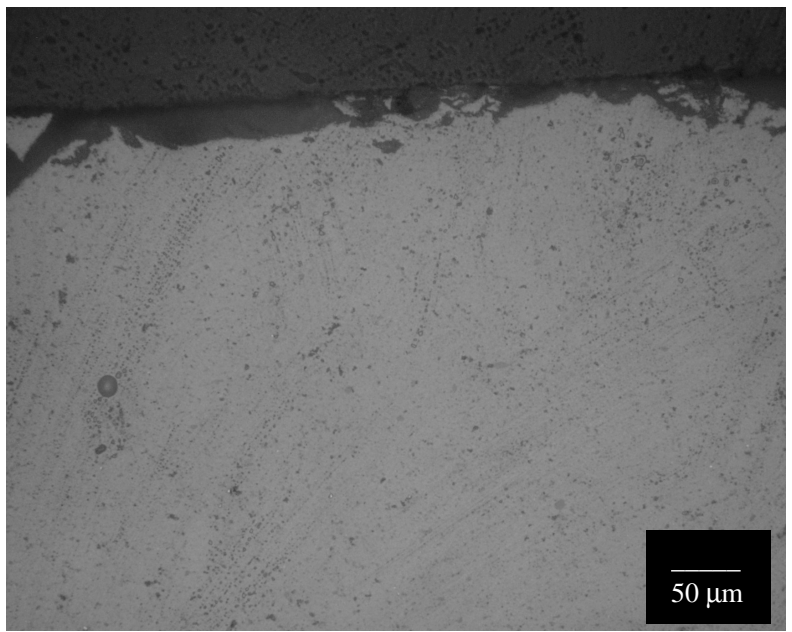

(a)

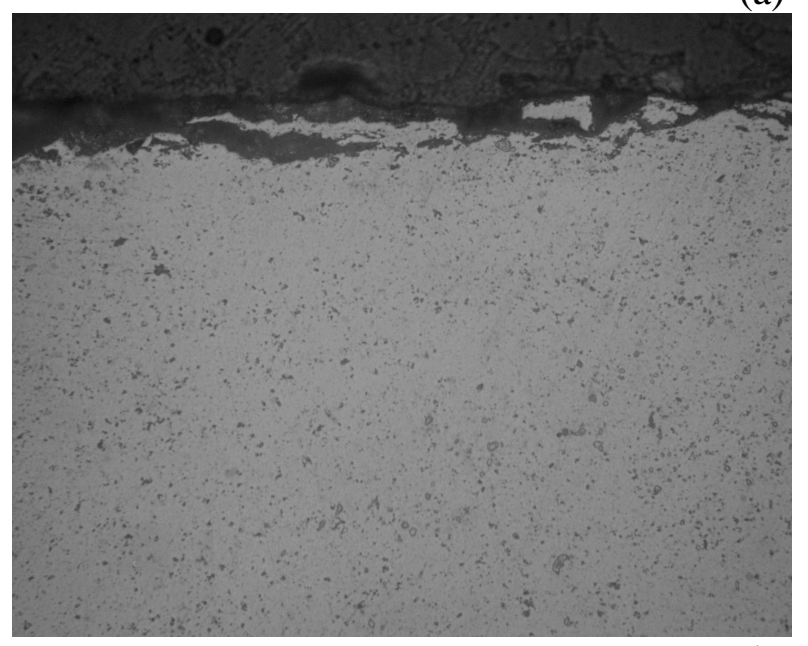

\section{$\overline{50 \mu \mathrm{m}}$}

(b)

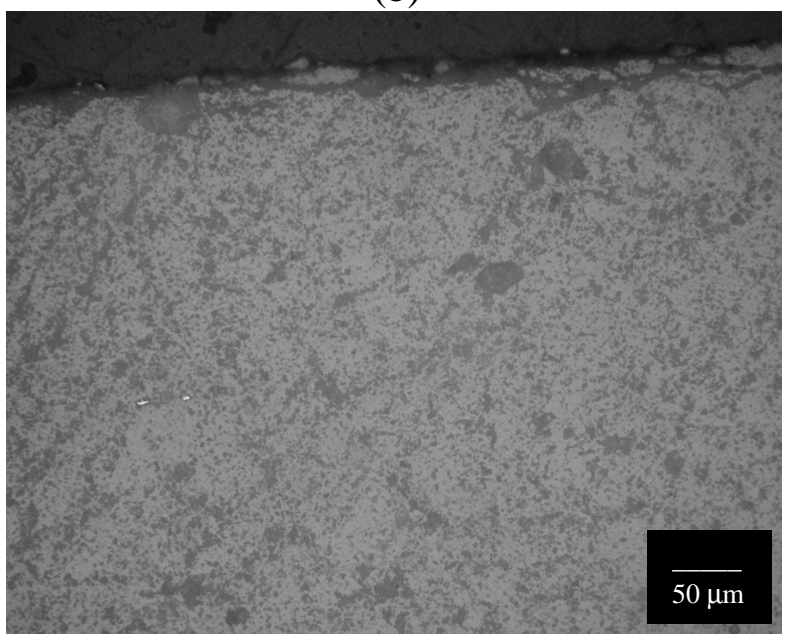

(c)

Figure 3.8: Optical microscopy Micrographs of Electrolyte Cross Sections of Hot Pressed YSZ Powder.(a) 1200, (b) 1100 , and (c) $1000{ }^{\circ} \mathrm{C}$. 


\section{Cathode Development}

The LSM powder was hot pressed using the identical parameters as the electrolyte, $1100^{\circ} \mathrm{C}, 2500 \mathrm{psi}$ and 30 minutes of hold time. The resulting microstructure showed adequate porosity for an SOFC electrode as estimated from optical microscopy.

The LSM cathode powder and YSZ electrolyte powder were layered and hot pressed at $1100^{\circ} \mathrm{C}, 2500 \mathrm{psi}$, with 30 min hold time. This result is shown in Fig. 3.9a.

Sintering characteristics of the components, when hot pressed in tandem, remained the same as when hot pressed separately. The relative density of the electrolyte remained the same as when pressed individually. The cathode showed adequate porosity and pore distribution for a SOFC electrode. Interfacial contact was excellent, with no boundary interactions optically evident, as shown in Fig. 3.9b. Therefore the hot pressing parameters for the electrolyte and cathode powders had converged.

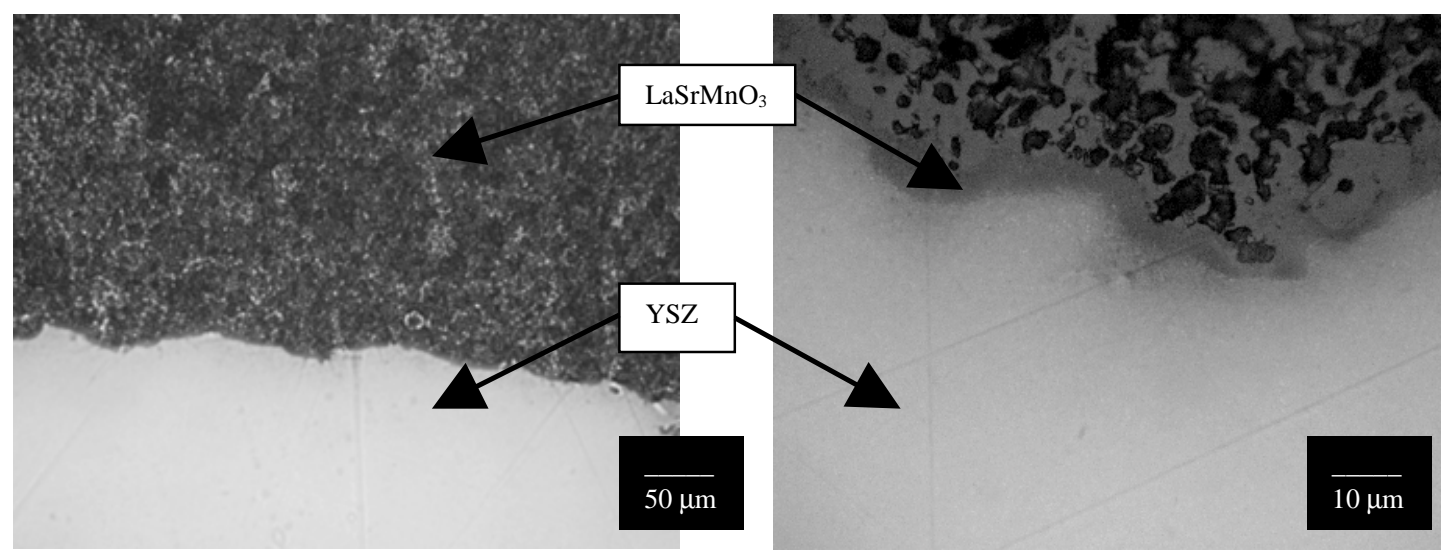

(a)

(b)

Figure 3.9: Optical Micrographs of Cathode/ Electrolyte Half Cell. 


\section{Anode Development}

A SOFC anode consists of 30 to 40 vol\% nickel with the balance YSZ and approximately $20-40 \%$ porosity. The anode is processed with $\mathrm{Ni}$ in its oxide form and reduced in situ as the cell begins operating in the fuel gas of $95 \% \mathrm{H}_{2}-5 \% \mathrm{H}_{2} \mathrm{O}$ at $1000^{\circ} \mathrm{C}$. This process has been found to take place in a matter of minutes under these conditions [18].

High temperature use of the hot press necessitates graphite as structural material for the heating elements. The carbon environment was highly reducing, since only a limited amount of oxygen was present (from the NiO). Therefore the atmosphere is controlled by the presence of carbon monoxide, as described by eq. 3.3. The change in Gibbs Free Energy, at $1100^{\circ} \mathrm{C}$, for this reaction is $-68.943 \mathrm{~kJ}$ and equilibrium constant is shown in eq. 3.4 [51].

$$
\begin{aligned}
& \mathrm{C}+\mathrm{CO}_{2}(\mathrm{~g})=2 \mathrm{CO}(\mathrm{g}) \\
& \mathrm{k}_{\text {equilibrium }}=\mathrm{P}_{\mathrm{CO}}^{2} / \mathrm{P}_{\mathrm{CO} 2}=419.6
\end{aligned}
$$

Thermodynamically, the graphite environment caused reduction of the $\mathrm{NiO}$ through the formation of carbon dioxide, as shown in eq. 3.5. The change in Gibbs Free Energy, at $1100^{\circ} \mathrm{C}$, for this reaction was $-160 \mathrm{~kJ}$ and equilibrium constant is shown in eq. 3.6 [51]. The negative change in Gibbs Free Energy for this reaction above $300^{\circ} \mathrm{C}$, 
resulted in a driving force for the reduction of $\mathrm{NiO}$ through a solid state reaction over the entire hot pressing experimental regime.

$$
\begin{aligned}
& 2 \mathrm{NiO}+\mathrm{C}=2 \mathrm{Ni}+\mathrm{CO}_{2}(\mathrm{~g}) \\
& \mathrm{k}_{\text {equilibrium }}=\mathrm{P}_{\mathrm{CO} 2}=1.39 \times 10^{6}
\end{aligned}
$$

After this reduction took place, the Ni metal that formed physically separated the $\mathrm{C}$ and $\mathrm{NiO}$. There was no longer intimate contact between the graphite and the NiO. Any further reduction took place though the gas phase reaction of $\mathrm{NiO}$ and $\mathrm{CO}$ as described in eq. 3.7. The change in Gibbs Free Energy, at $1100^{\circ} \mathrm{C}$, for this reaction was $-46 \mathrm{~kJ}$ and the equilibrium constant is shown in eq. 3.8 [51].

$$
\begin{aligned}
& \mathrm{NiO}+\mathrm{CO}(\mathrm{g})=\mathrm{Ni}+\mathrm{CO}_{2}(\mathrm{~g}) \\
& \mathrm{k}_{\text {equilibrium }}=\mathrm{P}_{\mathrm{CO} 2} / \mathrm{P}_{\mathrm{CO}}=57.4
\end{aligned}
$$

The equilibrium of $\mathrm{Ni}$ and $\mathrm{NiO}$ was controlled by the temperature and the oxygen partial pressure of the atmosphere at which the equilibrium took place. Any $\mathrm{CO}_{2}$ which formed reacted with the carbon components of the hot press according to eq. 3.3. At all temperatures, the equilibrium oxygen partial pressure in the hot press was controlled by the reaction in eq. 3.3 as discussed above. The log of the equilibrium oxygen partial pressure (see Appendix A) of this reaction is plotted versus the $\mathrm{Ni} / \mathrm{NiO}$ equilibrium oxygen partial pressure in Fig. 3.10. In an analogous manner to an Ellingham Diagram, 
$\mathrm{NiO}$ was stable for any value of oxygen partial pressure above the equilibrium value, while $\mathrm{Ni}$ was stable for partial pressures below these values. Additionally, the equilibrium oxygen partial pressure set by the carbon components in the hot press (eq. 3.3) is plotted in Fig. 3.10. As is evident from the plot, Ni was stable at all temperatures since the oxygen partial pressure was set by eq. 3.3. Hence, NiO reduction could have thermodynamically taken place during the hot pressing of the anode powder over the entire experimental regime.

The densification of the anode was studied at $1100^{\circ} \mathrm{C}, 2500 \mathrm{psi}$ and a 30 min hold time, using the processing parameters established for YSZ electrolyte and LSM cathode. The results of this experiment are shown in Fig. 3.11a. A continuous layer of $\mathrm{Ni}$, approximately 75 to $100 \mu \mathrm{m}$ thick, was evident on the surface. This thin, seemingly ineffectual, Ni layer can cause major problems for the operation of the final anode. A continuous metal layer acts as a blocking electrode inhibiting ionic transport through the cell. Additionally, a continuous layer hinders gas transport from the electrodes.

The reduction of the sample in Fig. 3.11a was attempted by heating the sample to $1000^{\circ} \mathrm{C}$ in a gas mixture of $95 \%$ Ar $5 \% \mathrm{H}_{2}$ for $2 \mathrm{hrs}$. The gas mixture was bubbled through distilled water at room temperature and was saturated at $3 \% \mathrm{H}_{2} \mathrm{O}$ before entering the furnace (see Fig. 3.10 for Oxygen partial pressure of this reaction).

The NiO did not fully reduce as shown in Fig. 3.11b. The Ni layer had sealed the inside of the anode from the reducing atmosphere. Therefore, a thin Ni layer can result in incomplete reduction of the $\mathrm{NiO}$ at later stages of processing due to lack of adequate porosity to allow gas transport, thereby rendering the anode unusable. 


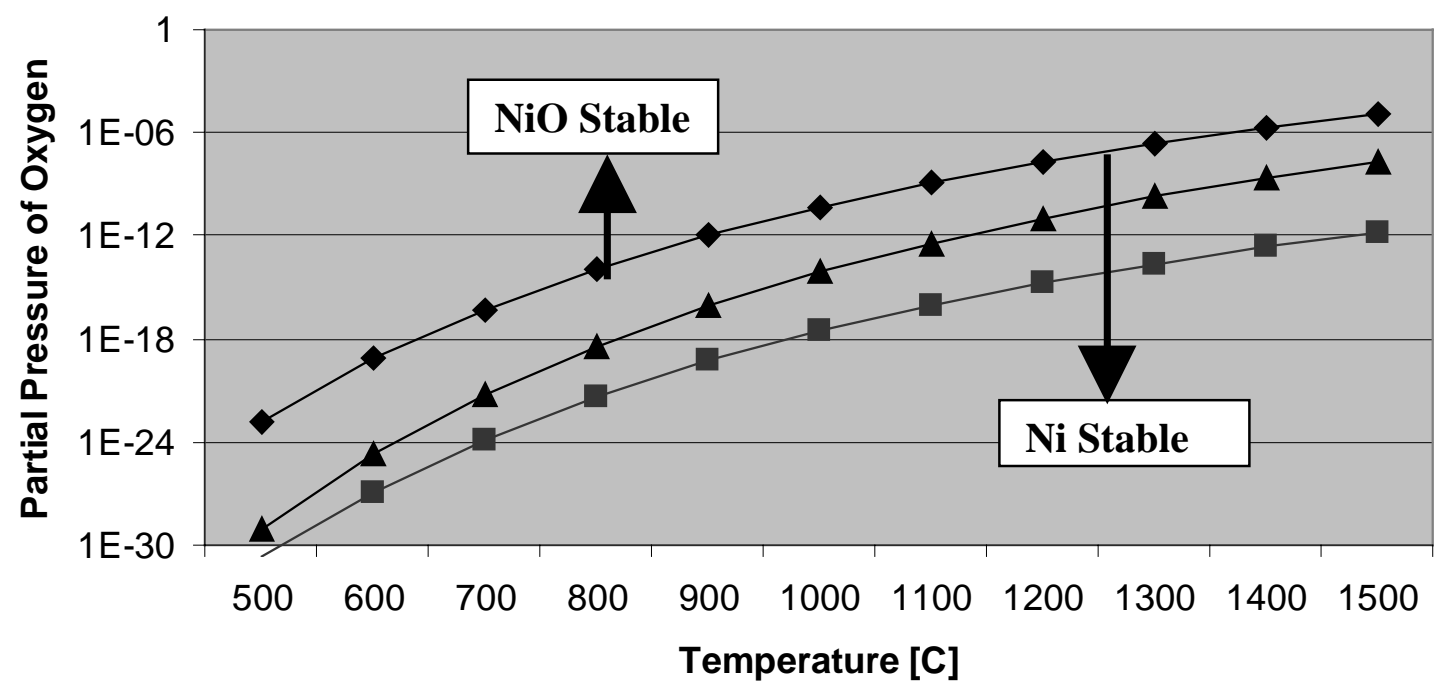

$\bullet-2 \mathrm{Ni}+\mathrm{O} 2(\mathrm{~g})=2 \mathrm{NiO}-2 \mathrm{CO}(\mathrm{g})+\mathrm{O} 2(\mathrm{~g})=2 \mathrm{CO} 2(\mathrm{~g})-2 \mathrm{H} 2(\mathrm{~g})+\mathrm{O} 2(\mathrm{~g})=2 \mathrm{H} 2 \mathrm{O}(\mathrm{g})$

Figure 3.10: Equilibrium Oxygen Partial Pressure of $\mathrm{Ni} /$ and $\mathrm{NiO}$ as a Function of Temperature.

\section{Elimination of Ni Reaction Layer}

Experimental modifications were made to reduce the driving force and kinetics for $\mathrm{NiO}$ reduction during hot pressing. This was accomplished by attempting to control the oxygen partial pressure where the reaction takes place, at the sample surface.

YSZ discs were used to isolate the $\mathrm{NiO}$ from the carbon environment during hot pressing. With $\mathrm{NiO}$ sandwiched between these plungers, the compact was hot pressed at $1100^{\circ} \mathrm{C}, 2500 \mathrm{psi}$, with a 30 min hold. Hot pressed samples processed using a carbon sleeve and YSZ plungers are shown in Fig. 3.11a and Fig. 3.11c, respectively. Substantial reduction in the thickness of the Ni reaction layer was evident. However, even after this modification, a thin layer of Ni was still present at the sample surface. 


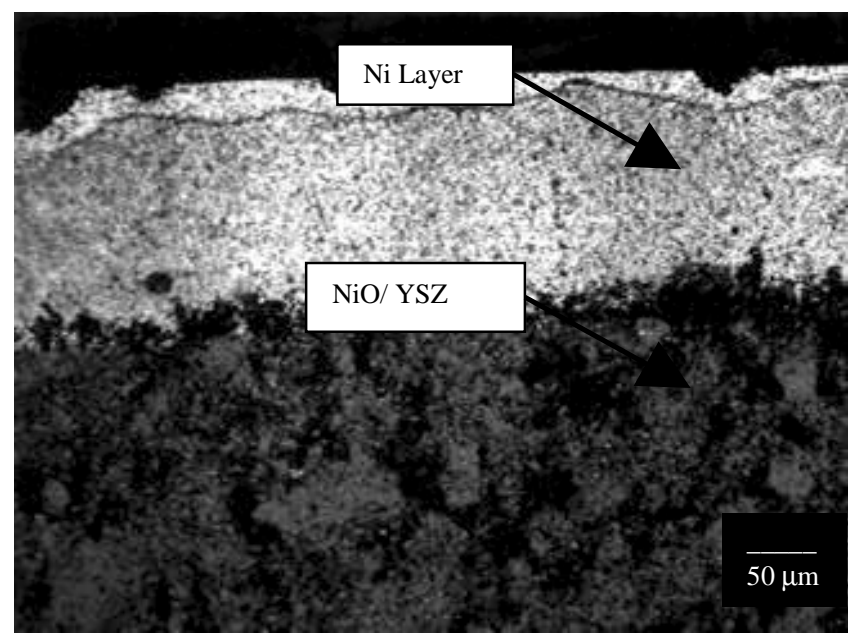

(a)

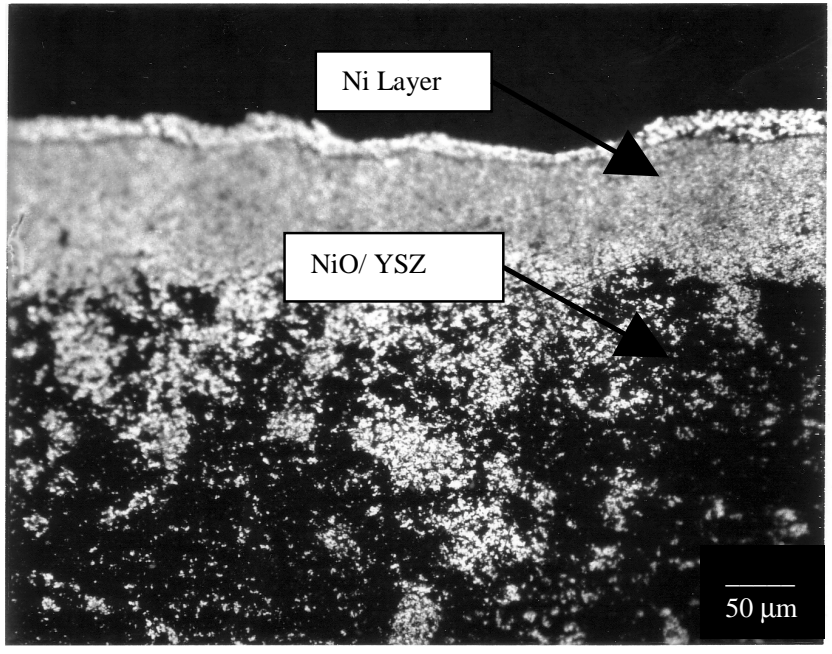

(b)

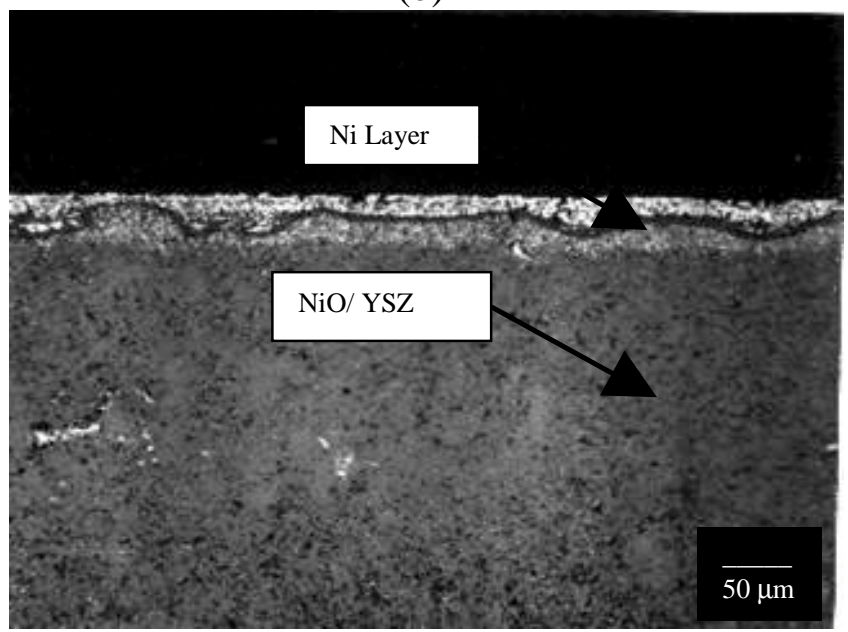

(c)

Figure 3.11: Various Hot Pressed Anode Powders (a) NiO and YSZ Powders (b) Post Reduction of (a) (c) Use of Non- Reactive Plungers. 
Further extension of this isolation concept incorporates fully inert die and sleeves. Elimination of the carbon sleeve and plunger was accomplished using an alumina tube and discs. By hot pressing in an environment without any direct contact between $\mathrm{NiO}$ and carbon, the thickness of the Ni layer could be further reduced. However the presence of the low oxygen partial pressure around the die assembly still seemed to draw oxygen from the $\mathrm{NiO}$.

\section{Oxidizing Environment}

For NiO to remain stable (eq. 3.9), the partial pressure of oxygen must remain above $1.17 \times 10^{-9} \mathrm{~atm}$. at $1100^{\circ} \mathrm{C}[52]$.

$$
2 \mathrm{NiO}=2 \mathrm{Ni}+\mathrm{O}_{2}(\mathrm{~g})
$$

Therefore, hot pressing $\mathrm{NiO}$ in an oxidizing partial pressure should not allow any reduction of the oxide. $\mathrm{NiO}$ was hot pressed in air at $1100^{\circ} \mathrm{C}, 2500 \mathrm{psi}, 30 \mathrm{~min}$ hold in an alumina die and sleeve. Results of this experiment are shown in Fig. 3.12. Notice that no elemental $\mathrm{Ni}$ is found in the cross section or at the die/ powder compact interface. The $\mathrm{NiO}$ reduction problem can be eliminated if an oxidizing environment is used.

Since the LSM cathode operates in an oxidizing atmosphere while the YSZ electrolyte is stable in both oxidizing and reducing environments [18], the oxidizing atmosphere results confirm that SOFCs can be hot pressed in a single step to produce the 
desired microstructures in the anode/ electrolyte / cathode components. However, as explained in the experimental details section, the apparatus used for hot pressing in air produced samples with a maximum diameter of $0.8 \mathrm{~cm}$. These samples were too small for electrochemical testing. Therefore, an alternative anode material was selected, so that the overall concept of one step hot pressing of SOFCs could be tested.

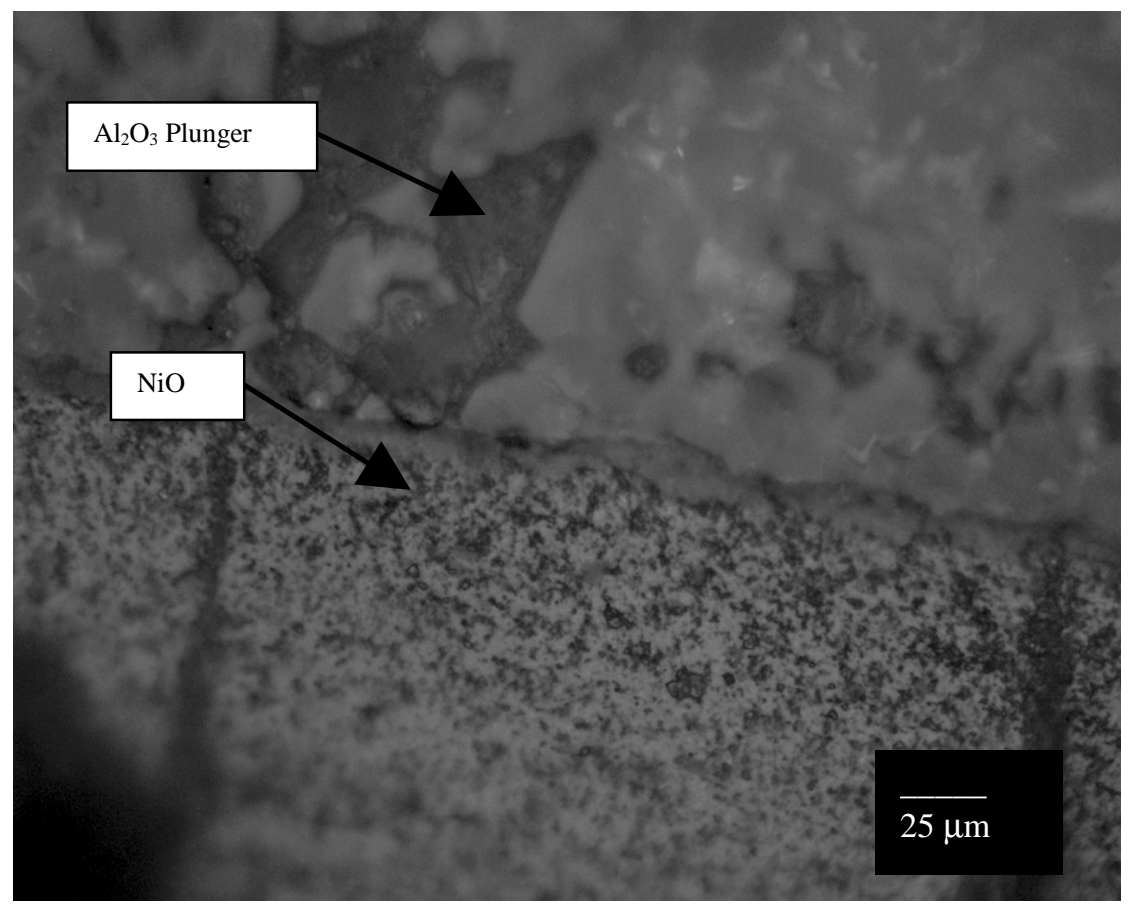

Figure 3.12: NiO Powder Hot Pressed in an Oxidizing Environment. $\mathrm{Al}_{2} \mathrm{O}_{3}$ Plunger (top) / $\mathrm{NiO}$ (bottom) interface shown.

\section{Anode 2: Mo and YSZ}

Due to the difficulties involved with hot pressing a $\mathrm{NiO}$ anode, it became necessary to search for alternative anode materials. Several alternatives to a Ni-based anode were investigated by other researchers, and a Mo-YSZ anode was recommended 
[52]. Mo was found to offer stability in the reducing SOFC fuel mixture environment and formed no insulating phases with YSZ. Additionally, Molybdenum's electrical resistivity compares favorably with $\mathrm{Ni}, \rho_{\mathrm{Mo}}=5.20 \mu \Omega$-cm while $\rho_{\mathrm{Ni}}=6.84 \mu \Omega$-cm [50].

To evenly distribute the YSZ phase throughout the anode, 0.2 um YSZ powder was used. This resulted in an even, uniform and controlled microstructure with greater than $40 \%$ porosity. The uniformly distributed YSZ cannot be distinguished optically as a second phase.

The Mo based anode was then hot pressed with the YSZ electrolyte. However, the Mo anode did not adhere to the electrolyte resulting in poor interfacial contact. This micrograph is shown in Fig. 3.13. The use of this anode would result in increased charge transfer resistance and unsatisfactory performance. Therefore the development of a new anode system was explored.

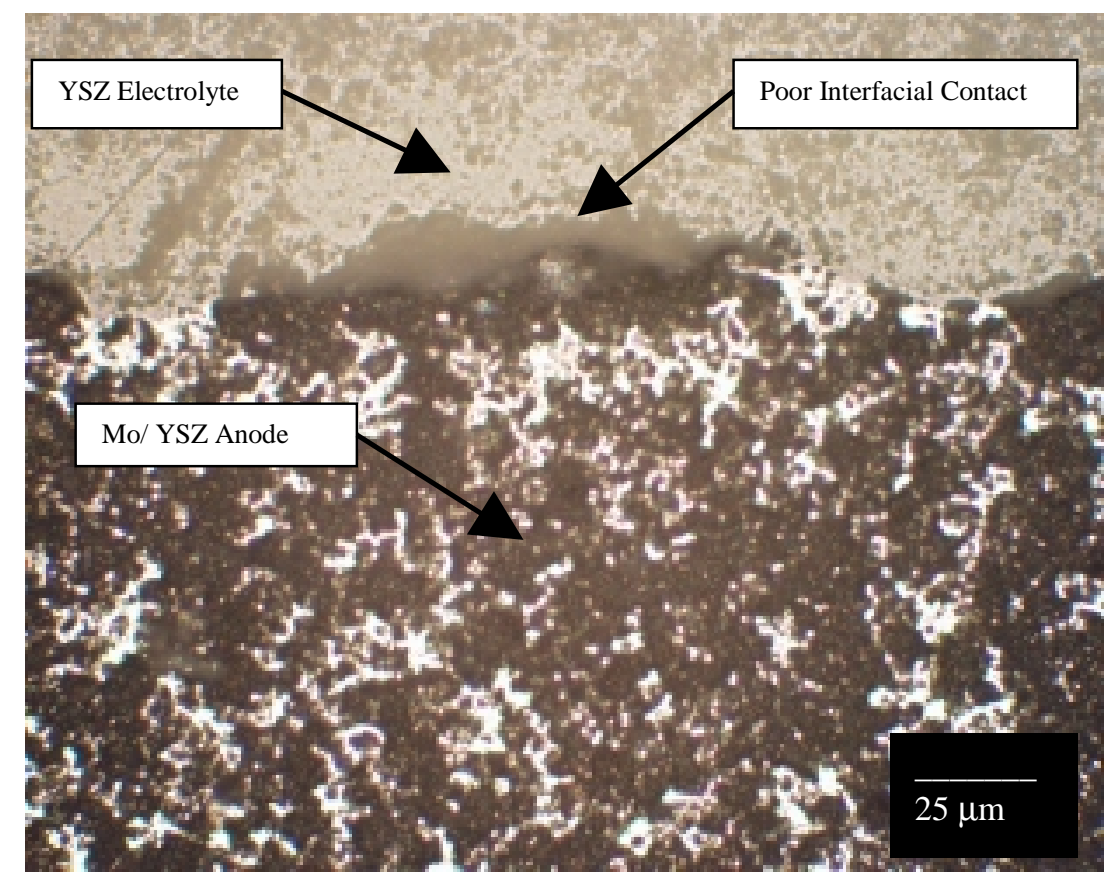

Figure 3.13: Hot Pressed Mo/ YSZ Anode and YSZ Electrolyte. 


\section{Anode 3: Mo/ 3\% Ni and YSZ}

An adherence problem between Molybdenum based anodes and YSZ electrolyte has been encountered before [52]. The solution pursued by these researchers was to change the surface properties and/or increase diffusive flux through the addition of $3 \mathrm{wt} \%$ Ni to the pure Mo. Examination of the Mo-Ni phase diagram, Fig. 3.14 [52], shows a maximum 3 wt\% nickel solubility before the formation of a Mo-Ni intermetallic. Therefore an anode composition of slightly greater than $3 \mathrm{wt} \% \mathrm{Ni}$ in Mo was used for the metallic composition of the anode.

The Mo/ YSZ anode and YSZ electrolyte powders were layered and hot pressed at $1100^{\circ} \mathrm{C}, 2500 \mathrm{psi}$, with a $30 \mathrm{~min}$ hold time. The resultant microstructure represents a good balance of uniformity, distribution and pore size (Fig. 3.15). The relative density of the electrolyte remains the same as when pressed alone. The anode, when pressed in tandem, showed adequate porosity and pore distribution for a SOFC electrode. Interfacial contact was excellent, with no boundary interactions evident. 


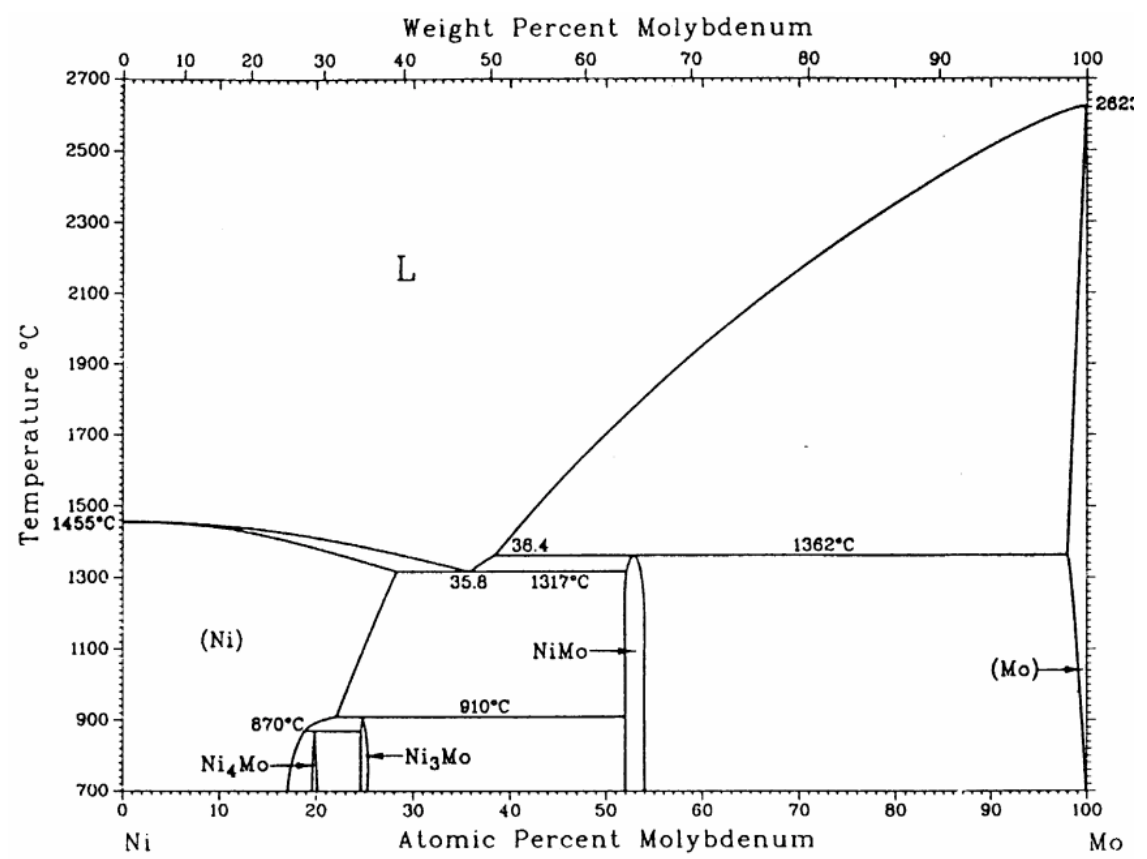

Figure 3.14: Mo-Ni Binary Phase Diagram.

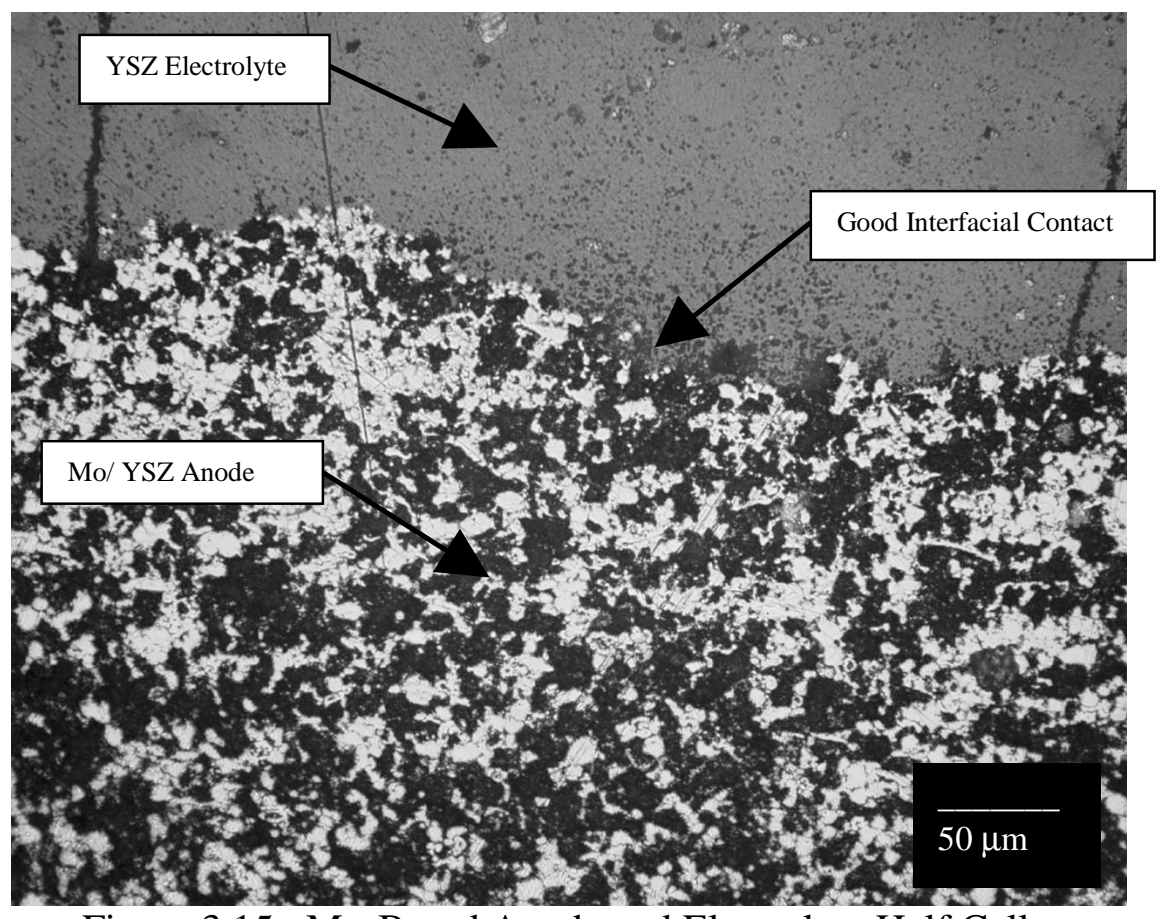

Figure 3.15: Mo-Based Anode and Electrolyte Half Cells. 


\section{Single Cell}

Finally the entire single cell was hot pressed using the established individual component parameters.

Mo/ YSZ anode powder, YSZ electrolyte powder, and LSM cathode powder were hot pressed at $1100^{\circ} \mathrm{C}, 2500 \mathrm{psi}$, with a $30 \mathrm{~min}$ hold, in a reducing environment. A micrograph of the anode/ electrolyte interface and cathode electrolyte interface is shown

in Fig. 3.16a and Fig. 3.16b, respectively. The electrolyte has greater than $90 \%$ relative density and closed porosity. The anode and cathode show adequate porosity for SOFC electrodes and excellent interfacial contact.

\section{Electrochemical Characterization}

Preliminary electrochemical investigations are being performed. 


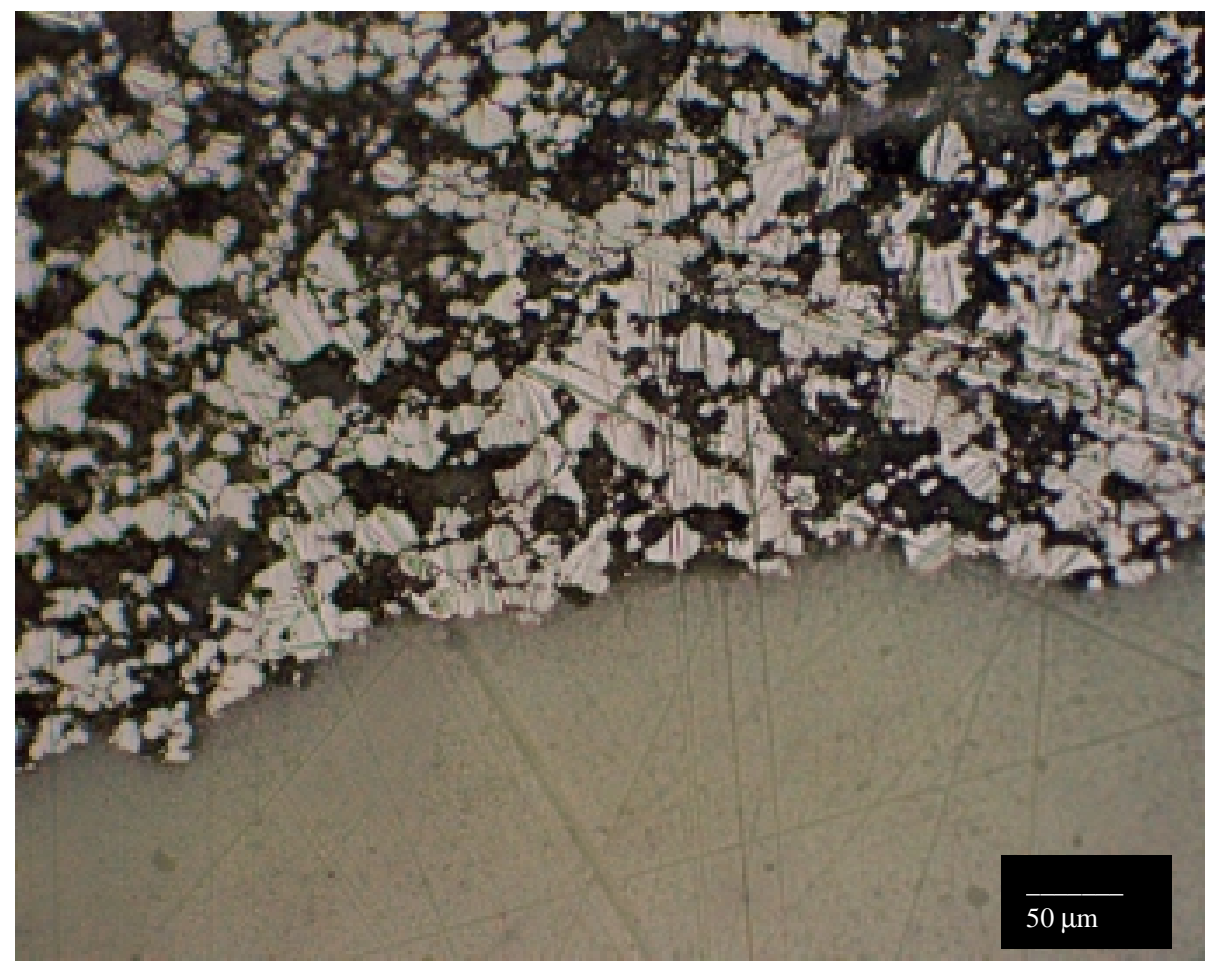

(a)

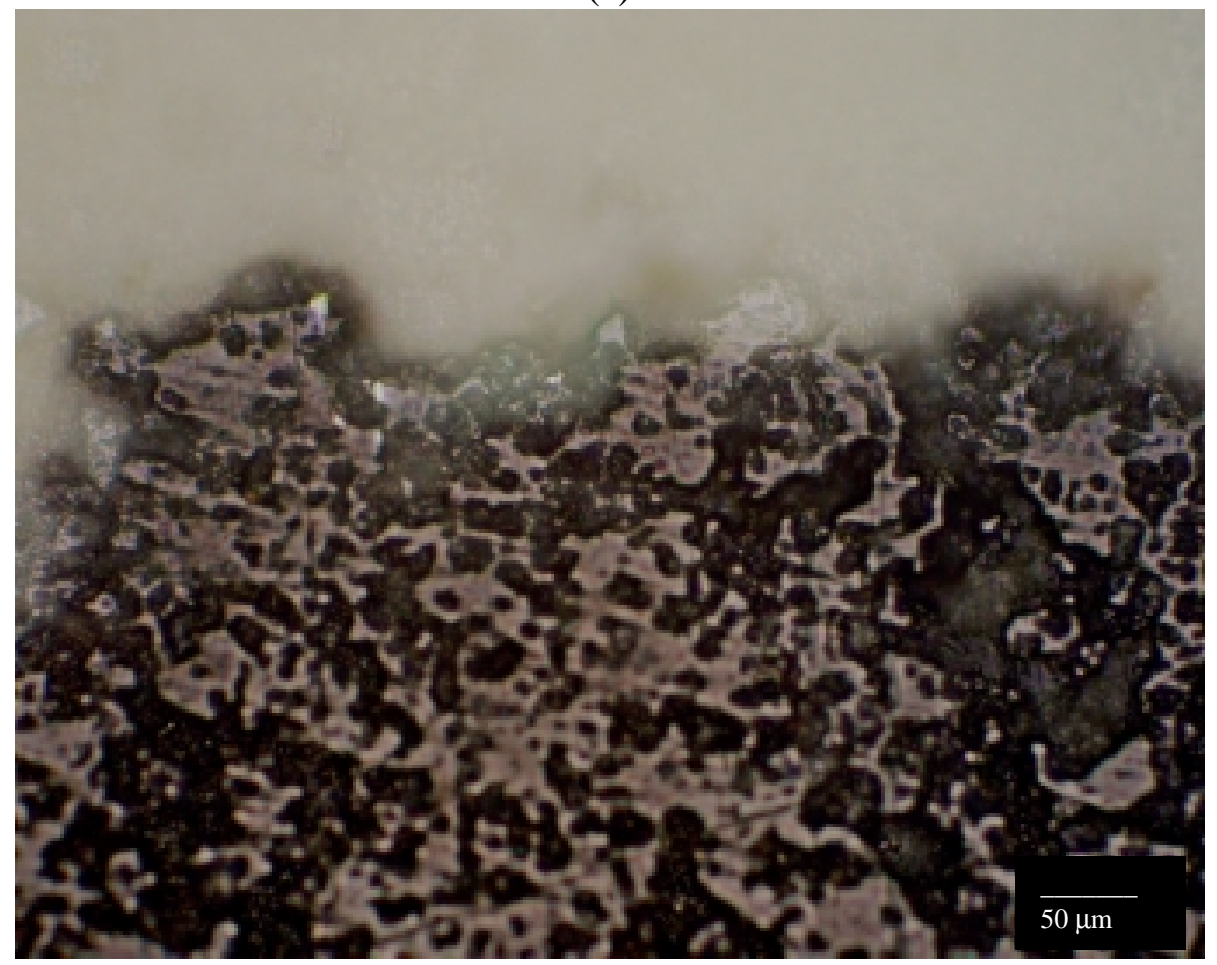

(b)

Figure 3.16: Moly-Based Anode, Single Cell, in a Reducing Environment. (a) Anode / Electrolyte interface, (b) Cathode / Electrolyte interface. 


\section{Chapter 4}

\section{CONCLUSIONS}

Over the course of this research, the fundamental knowledge related to ceramic processing, sintering, and hot pressing to successfully hot press a single operational SOFC in one step has been developed. Ceramic powder processing for each of the components of an SOFC has been tailored towards this goal. Processing parameter for the electrolyte and cathode have been studied and developed until they converged. Several anode fabrication techniques have been developed. Additionally, a novel anode structured has been developed and refined. These individual processes have been cultivated until a single cell SOFC has been fabricated in one step. 


\title{
Appendix A
}

\section{OXYGEN PARTIAL PRESSURE CALCULATION}

\author{
Nickel/ Nickel Oxide Equilibrium:
}

The Nickel/ Nickel Oxide equilibrium was the inverse of the equilibrium constant for eq. A.1, as shown in eq. A.2 and eq. A.3. This was plotted over the temperature range $500^{\circ} \mathrm{C}$ to $1500^{\circ} \mathrm{C}$.

$$
\begin{aligned}
& 2 \mathrm{NiO}=2 \mathrm{Ni}+\mathrm{O}_{2}(\mathrm{~g}) \\
& K_{1}=\frac{1}{P_{O 2}} \\
& P_{O 2}=\frac{1}{K_{1}}
\end{aligned}
$$

Hydrogen/ Water Vapor Equilibrium:

The oxygen partial pressure of eq. A.4 was solved for as described in eq. A.5 and eq. A.6. Assuming the inputted gas is pure hydrogen bubbled through water at a known temperature the hydrogen/ water vapor ratio can be calculated. The partial pressure of oxygen was plotted versus temperature. 


$$
\begin{aligned}
& 2 \mathrm{H}_{2}(\mathrm{~g})+\mathrm{O}_{2}(\mathrm{~g})=2 \mathrm{H}_{2} \mathrm{O}(\mathrm{g}) \\
& K_{2}=\left(\frac{P^{2}{ }_{\mathrm{H} 2 O}}{P^{2}{ }_{\mathrm{H} 2}}\right) \frac{1}{P_{O 2}} \\
& P_{O 2}=\frac{1}{K_{2}}\left(\frac{P^{2}{ }_{\mathrm{H} 2 O}}{P^{2}{ }_{\mathrm{H} 2}}\right) \\
& P_{O 2}=\frac{1}{K_{2}}\left(\frac{0.03^{2}}{0.97^{2}}\right)
\end{aligned}
$$

\section{Carbon Monoxide/ Carbon Dioxide Equilibrium:}

The oxygen partial pressure of eq. A.8 was solved for as described in eq. A.9 and eq. A.10.

$$
\begin{aligned}
& 2 \mathrm{CO}(\mathrm{g})+\mathrm{O}_{2}(\mathrm{~g})=2 \mathrm{CO}_{2}(\mathrm{~g}) \\
& K_{3}=\left(\frac{P^{2} \mathrm{CO}_{2}}{P^{2} \mathrm{CO}}\right) \frac{1}{P_{\mathrm{O} 2}} \\
& P_{O 2}=\frac{1}{K_{3}}\left(\frac{P^{2}{ }_{\mathrm{CO} 2}}{P^{2} \mathrm{CO}}\right)
\end{aligned}
$$

The partial pressure of oxygen was plotted for $500^{\circ} \mathrm{C}$ to $1500^{\circ} \mathrm{C}$ as described in eq. A.7. The carbon monoxide/ carbon dioxide equilibrium was calculated using the equilibrium constant of eq. A.11, as shown in eq. A.12. Finally the total pressure in the 
system, the vacuum pressure of the hot press (A.13) was used to find the three vapor phase equilibrium. Three equation and three unknowns were solved simultaneously and used to plot equation A.10 versus temperature.

$$
\begin{aligned}
& 2 \mathrm{CO}(\mathrm{g})=\mathrm{C}+\mathrm{CO}_{2}(\mathrm{~g}) \\
& K_{4}=\left(\frac{P_{\mathrm{CO} 2}}{P^{2} \mathrm{CO}}\right) \\
& P_{\text {Total }}=P_{\mathrm{CO}}+P_{\mathrm{CO} 2}+P_{O 2}
\end{aligned}
$$




\section{Appendix B}

\section{MOLYBDENUM BASED ANODE MAXIMUM FUEL UTILIZATION}

Fuel Utilization $(\mathrm{U})$ refers to the fraction of the total fuel or oxidant introduced into a fuel cell that reacts electrochemically, it is described in eq. B.1. For a Molybdenum based anode the maximum amount of hydrogen consumed is controlled by the oxidation limit of water vapor in the surrounding atmosphere before Molybdenum dioxide forms. Therefore this was first determined.

$$
U_{f}=\frac{H_{2, \text { In }}-H_{s, \text { Out }}}{H_{2, \text { In }}}=\frac{H_{2, \text { Consumed }}}{H_{2, \text { In }}}
$$

The oxidation limit of Molybdenum was found according to eq. B.2. The maximum water vapor content of the surrounding atmosphere was found using eq. B.4 eq. B.5 and eq. B.6.

$$
\begin{aligned}
& \mathrm{Mo}+2 \mathrm{H}_{2} \mathrm{O}(\mathrm{g})=\mathrm{MoO}_{2}+2 \mathrm{H}_{2}(\mathrm{~g}) \\
& K_{1}=\left(\frac{P^{2}{ }_{H 2}}{P^{2}{ }_{H 2 O}}\right)=1.589 \text { (at } 1000^{\circ} \mathrm{C}[52] \\
& P_{H 2 O}=\frac{P_{H 2}}{\sqrt{K_{1}}}=0.7933 * P_{H 2}
\end{aligned}
$$




$$
\begin{aligned}
& P_{\text {Total }}=P_{H 2 O}+P_{H 2}=0.7933+1=1.7933 \\
& P_{H 2 O}{ }^{M A X}=\frac{P_{H 2 O}}{P_{\text {Total }}}=\frac{0.7933}{1.7933}=0.442
\end{aligned}
$$

Assuming a starting hydrogen partial pressure of 0.97 , and a minimum exiting hydrogen partial pressure of 0.558 (see eq. B.6), the maximum fuel utilization is $54.4 \%$ for a Mo-based Anode, as described in eq. B.7.

$$
U_{f}=\frac{0.97-0.558}{0.97}=0.424
$$




\section{BIBLIOGRAPHY}

1. J. Mark. "Zeroing out Pollution: The Promise of Fuel Cells." Union of Concerned Scientists, 1996.

2. J. Ginsburg, "The Most Fuel-Efficient That You Can Be," Business Week, Sept. 3, 2001, p. 77-78.

3. Motor Vehicle Facts and Figures. American Automobile Manufacturers Association, 1998.

4. F. R. Kalhammer, et. al. "Status and Prospects of Fuel Cells as Automobile Engines." Prepared for the State of California Air Resources Board, July, 1998.

5. K. Kozloff, "Power to Choose." in Frontiers of Sustainability. World Resources Institute, Island Press, 1997.

6. "Distributed Generation, Securing America's Future with Reliable, Flexible Power," U.S. Department of Energy, Office of Fossil Energy, National Technology Center, October 1999.

7. C. Giovando, "Distributed Resources Carve Out a Niche in Competitive Markets," Power, July/August 2000, pp. 46-57.

8. "Natural Gas Fuel Cells, Federal Technology Alert," Federal Energy Management Program. U.S. Department of Energy, November 1995.

9. C. Campbell and J. H. Laherrere, "The End of Cheap Oil." Scientific American, March 1998.

10. G.D. Rambach and J.D. Synder. "An Examination of the Criteria Necessary for Successful Worldwide Deployment of Isolated, Renewable Hydrogen Stationary Power Systems." XII World Hydrogen Energy Conference, Buenes Aires, June 1998.

11. J. J. Mackenzie, "Oil as a Finite Resource: When is Global Production Likely to Peak?” World Resources Institute, March 1996.

12. D. Sperling. “A New Agenda," ACCESS, Number 11, University of California Transportation Center, Fall 1997.

13. http://energy.annualreviews.org/cgi/content/full/24/1/281. 
14. "Hydrogen Program Plan, FY 1993- FY 1997," U.S. Department of Energy.1998.

15. W.D. Kingery, H.K. Bowen, D.R. Uhlmann, Introduction to Ceramics $2^{\text {nd }}$ Ed., John Wiley \& Sons, New York 1976.

16. P.Murray, D.T. Livey \& Williams, "The Hot-Pressing of Ceramics," Ceramic Fabrication Processes, W.D. Kingery, Ed., Technology Press, M.I.T. \& John Wiley \& Sons (1958).

17. L. W. Fine and H. Beall, Chemistry for Engineers and Scientists, Saunders College Publishing, Philadelphia, 1990.

18. K. Kinoshita, F.R. McLarnon, E.J. Cairns, "Fuel Cells A Handbook, DOE/ METC-88/6096 (DE88010252)," U.S. Department of Energy, Office of Fossil Fuel, Morgantown, West Virginia, 1988.

19. A.J. Bard and L. R. Faulkner, Electrochemical Methods: Fundamentals and Applications, John Wiley \& Sons, New York, 1980.

20. N. Q. Minh and T/ Takahashi, Science and Technology of Ceramic Fuel Cells, Elsevier, New York, 1995.

21. Westinghouse Electric Corporation, "High-Temperature Solid Oxide Electrolyte Fuel Cell Power Generation System, Quarterly Summary Report, April 1, 1984June 30, 1984, Report No. DOE/ET/17089-2218," U.S. Department of Energy, Washington, DC, 1985.

22. K. M. Myles and C. C. McPheeters, "Monolithic Solid Oxide Fuel Cell Development," Journal of Power Sources, 29 (1990) 311-319.

23. "Performance and Cost Analysis of Monolithic Solid Oxide Fuel Cells 9466925," prepared for Department of Energy under contract De-Ac2189MC26006.

24. http://www.siemenswestinghouse.com/en/fuelcells/.

25. W.D. Kingery, H.K. Bowen, D.R. Uhlmann, Introduction to Ceramics $2^{\text {nd }}$ Ed., John Wiley \& Sons, New York 1976.

26. J. W. Evans and L. C. DeJonghe, The Production of Inorganic Materials, Macmillan Publishing Company, New Yor 1991.

27. R. M. German, Sintering Theory and Practice, John Wiley \& Sons, New York 1996. 
28. W.D. Kingery, "Pressure forming of Ceramics," Ceramic Fabrication Processes, ed. W.D. Kingery, John Wiley \& Sons., New York 1958. P. 55-61.

29. W.D. Kingery, "Hydrostatic Molding," Ceramic Fabrication Processes, ed. W.D. Kingery, John Wiley \& Sons., New York 1958. P. 70-73.

30. P. Duwez and L. Zwell, AIME Technical Pubublications 2515, Metals Transactions, 1, 137 (1949).

31. C.G. Goetzel, Treatise on Powder Metallurgy, Vol. 1, Interscience Publishing., New York (1949).

32. R. Kamm, M.A. Steinberg, and J. Wulff, Transactions AIME, 180, 694 (1949).

33. R. L. Coble, "Diffusion Models for Hot Pressing with Surface Energy and Pressure Effects as Driving Forces," Journal Of Applied Physics, 41.12 (1970) 4798-4807.

34. R. L. Coble, "Mechanisms of Densification During Hot Pressing," Sintering and Related Phenomena, Proceedings of the International Conference. Ed. G.C. Kuczynski, N.A. Hooton, C.F. Gibbon, Gordon and Breach, (1967). P. 329-347.

35. P. Murray, D.T. Livey, J. Williams, "The Hot Pressing of Ceramics," Ceramic Fabrication Processes, ed. W.D. Kingery, John Wiley \& Sons., New York 1958. P. 147-171.

36. F. R. N. Nabarro, Conference on Strength of Solids, Bristol, 1947, 48 (1948); C. Herring, Journal of Applied Physics 21, 437 (1950).

37. R. R. Rossi and R. M. Fulrath, Journal of the American Ceramic Society 48, 558 (1965).

38. D. L. Johnson, Scripta Metalurgica 3, 567 (1969).

39. S. K. Dutta and R. M. Spriggs, Material Research Bulletin. 4, 797 (1969).

40. R. L. Coble, Journal of Applied Physics, 34, 1970 (1963).

41. E-mail correspondence with Manny Gonzales, applications engineer for Poco Graphite. http://www.poco.com/industrial/value_axm5q.html.

42. J.A.M. van Roosmalen and E.H.P. Cordfunke, Solid State Ionics, 52 (1992) 303. 
43. C.C. Chen, M.M. Nasrallah, and H.U. Anderson, in Proceedings of the Third International Symposium on Solid Oxide fuel Cells, May 16-22, 1993, Honolulu, HI, S.C. Singhal and H. Iwahara (eds.), Electrochemical Society, Pennington, NJ, 1993, p. 598.

44. C.Clausen, C. Bagger, J.B. Bilde-Sorensen, and A. Horsewell, Solid State Ionics, 70/71 (1994) 59.

45. T. Kawada, N. Sakai, H. Yokokawa, M. Dokiya, and I. Anzai, Solid State Ionics, 50 (1992) 189.

46. T.R. Armstrong, L.A. Chick, and J.L. Bates, in Proceedings of the third International Symposium on Solid Oxide Fuel Cells, May 16-21, 1993, Honolulu, HI, S.C. Singhal H. Iwahara (eds.), Electrochemical Society, Pennington, NJ, 1993, p.632.

47. N.Q. Minh, in Proceedings of the third International Symposium on Solid Oxide Fuel Cells, November 13-14, 1989, Nagoya, Japan, O. Yamamoto, M. Dokiya, and H. Tagawa (eds.), Science House, Tokyo, Japan, 1989, p. 67.

48. N.Q. Minh, T.R. Armstrong, J.V. Guiheen, C.R. Horne, F.S. Liu, D.M. Moffatt. T.L. Stillwater, and J.J. Van Ackerson, in 1990 Fuel Cell Seminar Abstracts, November25-28, 1990, Phoenix, AZ, Courtesy Associates, Washington, DC, 1990, p.524.

49. M. Ciftcioglu and M.J. Mayo, paper presented at The Spring Meeting of the Materials Researh Society, April 16-21, 1990, San Francisco, CA, Report No. DE90-015700, SAND-90-1639C, CONF-900466-78, National Technical Information Service, Alexandria, VA, 1990.

50. CRC Handbook of Chemistry and Physics, 71 st Ed., Chemical Rubber Company, Boston 1990.

51. HSC Chemistry Version 3.0, Copyright @ Outokumpu Research Oy, Pori, Finland, A. Roine.

52. S. Joshi, Thesis: "Development Of Anode Coating For High Temperature Som Process", Boston University, Department of Manufacturing Engineering, Boston, 2002. 